NBER WORKING PAPER SERIES

\title{
WHEN DOES START-UP INNOVATION SPUR THE GALE OF CREATIVE DESTRUCTION?
}

\author{
Joshua S.Gans \\ David H. Hsu \\ Scott Stern
}

Working Paper 7851

http://www.nber.org/papers/w7851

\author{
NATIONAL BUREAU OF ECONOMIC RESEARCH \\ 1050 Massachusetts Avenue \\ Cambridge, MA 02138 \\ August 2000
}

We would like to thank the firms who participate in our Commercialization Strategies survey for their time and effort. Rebecca Henderson and Josh Lerner provided useful suggestions. We also gratefully acknowledge funding from the MIT Center for Innovation in Product Development under NSF Cooperative Agreement EEC-9529140 and from an Australian Research Council Large Grant. Stern completed this paper while an NBER Fellow in Health and Aging. Responsibility for all views expressed lies with the authors.

(C) 2000 by Joshua S. Gans, David H. Hsu, and Scott Stern. All rights reserved. Short sections of text, not to exceed two paragraphs, may be quoted without explicit permission provided that full credit, including (C) notice, is given to the source. 
When Does Start-Up Innovation Spur the Gale of Creative Destruction?

Joshua S. Gans, David H. Hsu, and Scott Stern

NBER Working Paper 7851

August 2000

JEL No. L10, L14, O31 and O32.

\begin{abstract}
This paper is motivated by the substantial differences in start-up commercialization strategies observed across different high-technology sectors. Specifically, we evaluate the conditions under which start-up innovators earn their returns on innovation through product market competition with more established firms (such as in many areas of the electronics industry) as opposed to cooperation with these incumbents (either through licensing, strategic alliances or outright acquisition as observed in the pharmaceutical industry). While the former strategy challenges incumbent market power, the latter strategy tends to reinforce current market structure. Though the benefits of cooperation include forestalling the costs of competition in the product market and avoiding duplicative investment in sunk assets, imperfections in the "market for ideas" may lead to competitive behavior in the product market. Specifically, if the transaction costs of bargaining are high or incumbents are likely to expropriate ideas from start-up innovators, then product market competition is more likely. We test these ideas using a novel dataset of the commercialization strategies of over 100 start-up innovators. Our principal robust findings are that the probability of cooperation is increasing in the innovator's control over intellectual property rights, association with venture capitalists (which reduce their transactional bargaining costs), and in the relative cost of control of specialized complementary assets. Our conclusion is that the propensity for pro-competitive benefits from start-up innovators reflects an earlier market failure, in the "market for ideas."
\end{abstract}

Joshua S. Gans

University of Melbourne

200 Leicester Street

Carlton, VIC 3053

AUSTRALIA

J.Gans@mbs.unimelb.edu.au
David H. Hsu

MIT Sloan School

50 Memorial Drive

Cambridge, MA 02142

dhsu@mit.edu
Scott Stern

MIT Sloan School

50 Memorial Drive

Cambridge, MA 02142

and NBER

sstern@mit.edu 


\section{Introduction}

Since the early 1990s, there has been an explosion in the level of investment funding provided to technology-oriented start-up firms in the United States. For example, venture capitalists invested at least $\$ 12.5$ billion in 1998 in the United States up over five-fold from 1991 (VentureOne, 2000; Rausch, 1998) - and venture-backed firms are now estimated to account for $15 \%$ of all domestic industrial innovation (Kortum and Lerner, 1999). Not surprisingly, there is considerable popular and academic interest in the potential implications of this surge in the rate of $R \& D$ investment in small, entrepreneurial firms (Gompers and Lerner, 1999; Kortum and Lerner, 1999; Christensen, 1997; Strasser, 1999).

One of the key issues raised by the dramatic rise in venture financing is the impact that the creation of these new firms will have on the dynamics of industrial organization in high-technology industries. In this paper, we address this issue by identifying the conditions under which the commercialization strategy chosen by a startup firm tends to reinforce (or, alternatively, overturn) incumbent market power. Specifically, we provide empirical evidence that whether start-ups compete or cooperate with established firms depends on more fundamental economic factors which shape both the value of cooperation relative to competition and the transactional costs of bargaining.

Our approach builds upon two competing perspectives on the product market consequences of start-up innovation. On the one hand, many analysts suggest that entrepreneurial activity ushers in systematic industrial restructuring in many hightechnology industries - newly financed companies compete with and then ultimately 
overturn the market power of established firms (Foster, 1986; Hobijn and Jovanovic, 1999; Christensen, 1997). According to this perspective, the small-firm R\&D financing boom is accelerating the "gale of creative destruction," the process by which new firms leverage the innovative process to replace established firms within specific industrial sectors (Schumpeter, 1943). In effect, proponents of this perspective are suggesting that because venture capital (and other financing institutions such as the provision of government subsidies to technology-oriented firms) have overcome (or at least substantially alleviated) the liquidity and incentive dilemmas which have traditionally limited the level of innovative activity by small firms, the rise of small firm $R \& D$ financing will be associated with systematic pro-competitive consequences.

However, both economic theory as well as a slightly more detailed recounting of the facts associated with venture-backed firms suggests that the link between entrant innovative activity and changes in market leadership may be more nuanced than commonly assumed. Conditional on developing a prototype of a new technology, a startup firm may calculate that greater profits may be earned (in expectation) through cooperation with established firms (either through licensing, joint venture, or outright acquisition of the potential entrant by the incumbent) rather than through product market competition with these same firms (Salant, 1984; Gallini and Winter, 1985; Anton and Yao, 1995; Gans and Stern, 2000a). In such a case, innovation-oriented start-up firms serve as upstream suppliers of technology to established firms rather than potential sources of disruption to current market structure.

Indeed, in the absence of significant imperfections which make a bargaining agreement between start-up and incumbent infeasible, these economic actors share two 
distinct gains from trade with each other: (1) the preservation of current market power within the industry and (2) the opportunity to avoid investment in duplicative commercialization assets, such as those which might be associated with distribution, manufacturing, or the establishment of a reputation for quality. As long as commercialization does not involve substantial diseconomies of scale or scope, observations of competition in the product market as the result of innovation by a start-up firm reflect a prior market imperfection - in the "market for ideas." If an ideas market functions well, this allows incumbents to contract for innovations from upstream start-ups and so forestall the competitive impact associated with entry.

Of course, these theoretical concerns would be of only limited interest if, in reality, start-up innovators exclusively chose to earn their returns through product market competition. 1 However, even a sector-level examination of commercialization strategy patterns suggests important heterogeneity. For example, in biotechnology, some form of cooperation is the norm (whether through licensing, strategic alliances or outright acquisition), while in some areas of electronics, such as the disk drive sector, start-up firms consistently earn their returns through direct participation in the product market (Orsenegio, 1989; Lerner and Merges, 1998; Christensen, 1997).

Motivated by this observed variation in entrant commercialization strategy, this paper focuses on the economic drivers of the commercialization path of research-oriented start-up firms. In particular, we document the linkage between small firm R\&D and

\footnotetext{
${ }^{1}$ Indeed, while the earliest empirical studies of the sources of returns from innovation typically found that "cooperation" (as proxied by technology licensing) was associated with modest revenues (Scherer, 1965; Caves, Crookwell, and Killing, 1983), more recent analyses have noted that (a) cooperation can take numerous forms, from licensing to strategic alliances to outright acquisition) and that (b) an increasing share of start-up returns seem to be associated with such strategies (US DOJ Licensing Guidelines, 1995; Arora, 1995; Chesbrough and Teece, 1998; VentureOne, 1999).
} 
creative destruction by explicitly examining the strategic choices made by start-up firms after they have developed a prototype technology.

Our analysis begins with a simple theoretical model of the commercialization decision of start-up firms. While both incumbents and innovator start-ups have incentives to avoid head-to-head competition or duplication of sunk investments, several factors may affect the probability of cooperation by introducing bargaining imperfections or changing the economies to cooperation.

First, a principal benefit from cooperation is the ability of start-up innovators to exploit "complementary assets" held by incumbent firms, such as through their control over distribution channels, regulatory or manufacturing expertise, or brand-name recognition (Teece, 1986). While avoiding duplication of these sunk assets will be important in fostering cooperation in some environments (such as when biotechnology firms are able to exploit the regulatory expertise of established pharmaceutical companies), incumbent-held assets will confer minimal value to start-up innovators in other settings (for example, when the start-up innovator has developed an incompatible technology). Whereas previous researchers have focused on how asymmetries in sunk assets affect the distribution of returns from innovation (Teece, 1986; Bresnahan, Stern, and Trajtenberg, 1997), our model suggests that such differences may also drive commercialization strategy: as the relative "cost" of competing increase, entrants will tend to forgo competition and instead earn their returns through the market for ideas.

Second, identifying and contracting with incumbent commercialization partners may involve "search" or transactional costs. Even when intellectual property (IP) rights are well defined, there may be uncertainty about the value (or other characteristics) of the 
start-up technology; such disagreements necessitate detailed bargaining between the parties about royalty rates and other contingent contracting provisions (Fosfuri, Arora, and Gambardella, 1999). In this case, the presence of bargaining "intermediaries" (such as venture capitalists or specialized legal counsel) may substantially reduce the cost of forging an agreement between the two parties (Fosfuri, Arora, and Gambardella, 1999; Burt, 2000). Accordingly, as bargaining costs decrease, the relative returns to cooperation increase.

Finally, there is a contracting hazard inherent in the nature of the innovative process: bargaining between entrant and incumbent requires the start-up to disclose the idea to the established firm (Arrow, 1962). In the absence of complete IP protection, the established firm may be able to expropriate the economic value of the entrant's invention through imitation. 2 This disclosure hazard will be particularly salient when IP rights are weak and so disclosed information substantially reduces the cost of imitation by the incumbent (Merges and Nelson, 1991; Anton and Yao, 1994). In such a case, a start-up innovator may choose to earn the rents on its innovation through the product market in order to avoid disclosing technical information to the incumbent. ${ }^{\text {B }}$ Or, stated another way, while IP likely increases the absolute returns to innovation regardless of commercialization strategy, IP also increases the relative returns to cooperation in many cases, precisely because it reduces the hazard of expropriation.

The main contribution of this paper is to evaluate empirically whether environments that differ along each of these dimensions - complementary assets, the cost

\footnotetext{
${ }^{2}$ Of course, if the start-up innovator's technology builds upon the inventions of the incumbent, an optimal IP regime would compensate the incumbent for part of the value generated by the follow-on innovator's technology (Scotchmer, 1991; Green and Scotchmer, 1995).
} 
of contracting, and the strength of intellectual property - are associated with substantially different start-up innovator commercialization patterns. Perhaps surprisingly, little empirical work has been devoted to this topic. By and large, prior analyses of the relationship between start-up and established firms have tended to focus on the relative incentives to innovate in the first place, under the assumption that innovation by a startup will be followed by product market competition with more established firms. ${ }^{4}$ As well, several analyses have examined the form of cooperation between smaller researchoriented firms and larger more established firms without considering the potential for product market entry. 5 B relating the choice between cooperation and competition to the firm's economic environment, our analysis suggests that the competitive consequences of start-up innovation are endogenous. Specifically, the industrial organization consequences of the small-firm R\&D financing boom depend on factors such as the strength of intellectual property and the availability of venture capital, which are themselves determined, at least in part, by various aspects of public policy.

We investigate the determinants of the commercialization path of a group of 118 small research-oriented firms, split almost equally between enterprises funded by venture capital and the US Federal government through the Small Business Innovation Research Program. We analyze three main hypotheses derived from our theoretical model. First, we consider whether innovations that receive some formal IP protection (e.g., a patent) are associated with higher levels of cooperative activity. Second, we examine whether

\footnotetext{
${ }^{3}$ Anton and Yao (1995) were the first to explicitly evaluate how the disclosure problem and the potential for expropriation impact the bargaining equilibrium between an incumbent and a potential start-up.

${ }^{4}$ The literature on R\&D and product market competition between incumbents and start-up firms is too large to be summarized here, but see, for example, Schumpeter, 1943; Scherer, 1965; Gilbert and Newbery, 1982; Reinganum, 1983; Kamien and Schwartz, 1982; Cohen and Levin, 1989; Scotchmer, 1991; Scherer, 1992; Henderson, 1993; Cockburn and Henderson, 1994; Lerner, 1997; and Christensen, 1997.
} 
start-up innovators who have access to control over downstream complementary product market assets (e.g., distribution channels or manufacturing capability) are more likely to vertically integrate into the product market. Finally, we consider whether start-up firms that have access to networks of contacts (e.g., through a relationship with a venture capitalist) are more likely to be able to contract with potential commercialization partners as the result of lower "search costs."

On their face, our empirical results are striking. Each of the above factors control over intellectual property, the attractiveness of control over complementary assets, and association with venture capitalists - is associated with a significant effect on the probability of cooperation by our sample of start-up innovators. For example, firms that possess intellectual property are estimated to be $23 \%$ more likely than non-patentholders to cooperate as part of their commercialization strategy. Moreover, our empirical findings are robust to the inclusion of a variety of controls and to focusing on withinindustry or cross-industry variation.

While we emphasize that our results are robust in a purely statistical sense, we are cautious about interpreting our results as a dispositive test of our theory of start-up commercialization strategy. Our empirical measures are imperfect: even though we include a large number of control variables, our results may be subject to bias. However, the chief "candidate " for bias - conflating strong intellectual property or association with venture capitalists with "high-quality" projects - will likely generate bias in the opposite direction of both our theory and empirical results. To see this more clearly, suppose that control over IP (or association with venture capitalists) is simply proxying for "high-

\footnotetext{
${ }^{5}$ See Salant, 1984; Katz and Shapiro, 1986; Pisano, 1990; Anton and Yao, 1995; Lerner and Merges, 1998; and Gans and Stern, 2000a.
} 
quality" or "radical" projects. Under this scenario, most earlier research would suggest that our measures of IP protection or lower bargaining costs would be associated with higher rates of independent product market entry by technological innovators (Foster, 1986; Shan, 1990; Pisano, 1990), precisely the opposite of our theoretical predictions and empirical findings. In other words, despite the relatively small size of our sample and our imperfect ability to measure the precise concepts underlying the theoretical model, we are able to demonstrate a fairly robust set of empirical findings which accord with a simple but novel model of strategic interaction between start-up innovators and incumbent firms in high-technology industries.

The remainder of this paper is organized as follows: the next section motivates the study by highlighting the heterogeneity of cooperation across technological sectors. We then develop a simple model exploring the economics of commercialization strategies. After a brief review of our data, we present our principal empirical results in Section V. A final section concludes.

\section{What is the Empirical Puzzle?}

Our analysis is motivated by a simple but important puzzle: start-up commercialization strategy varies substantially across industrial sectors. On the one hand, some research-intensive sectors are subject to a high rate of "creative destruction," whereby start-up innovation followed by product market entry serves as a key mechanism by which incumbent market power is overturned ${ }^{6}$ For example, in the hard disk drive

\footnotetext{
${ }^{6}$ While Schumpeter (1943) pioneered the study of the relationship between innovation and market structure, it was not until more systematic empirical anlysis began in the 1960s that the ambiguous nature of the relationship between innovation and market power became apparent (Scherer, 1965; Cohen and
} 
industry, each "generation" of technology (where a generation is defined according to disk drive size) has been pioneered by an entrant firm (see Figure A, drawn from Christensen, 1997); as well, the market leader associated with any one generation of technology has not been the market leader in the immediately preceding generation of technology.

On the other hand, in other industrial sectors, a high rate of innovation by start-up research-oriented firms is associated not with creative destruction but with the reinforcement of incumbent market power. Consider the biotechnology industry. While the radical technical and scientific breakthroughs promised by biotechnology were heralded originally as a force for creative destruction (USOTA, 1984), market leadership has remained relatively constant in the pharmaceutical industry over the past 25 years. As suggested by Table 1, not one of the ten largest independent pharmaceutical firms in 1997 have their origins in biotechnology; indeed, seven of the top ten firms in 1997 were among the top fifteen leaders by sales in 1973, and the remaining three - Abbott, Baxter, and SmithKline Beecham - all have their origins in the traditional pharmaceutical business and were well-established prior to the beginnings of the biotechnology "revolution."

This is not to suggest that biotechnology products have not been commercialized. Indeed, by 1997, over 55\% of all new products approved by the FDA in the United States are based, at least in part, on discoveries and drugs developed with the tools of biotechnology (Bioworld, 1998). As well, the internal R\&D departments of established pharmaceutical firms do not make the initial discoveries of the vast majority of these

Levin, 1989). More recently, the majority of empirical work in this area has been undertaken by scholars in the strategic management of technology and organizational sociology (Foster, 1986; Henderson and Clark, 
biotechnology products; instead, they represent the innovative outputs of researchoriented biotechnology firms who chose to cooperate with at least one incumbent pharmaceutical firm in the commercialization process (BioWorld, 1998). ${ }^{\square}$ This commercialization pattern allows for a high rate of innovation by start-up firms alongside stability in product market structure; incumbent firms avoid competition from potential start-up firms by choosing to cooperate through one of a number of strategies, from licensing to the formation of strategic alliances to outright acquisition of the start-up by the incumbent firm. In other words, in contrast to the disk drive industry where start-up innovators tend to earn their returns through competition in the product market, biotechnology firms tend to earn their returns on innovation through the market for ideas.

Our challenge is therefore to identify the key factors which differentiate these sectors and evaluate whether those factors help explain start-up innovator commercialization strategy patterns more generally. We do so by developing a simple but illustrative model of commercialization strategy in which a small set of key factors incumbent sunk assets, search costs, and the intellectual property protection afforded the start-up innovator - affect the relative attractiveness of cooperation versus competition.

\section{A Simple Model of Start-Up Commercialization Strategy}

In this section, we develop a theoretical model aimed at understanding the factors that drive a cooperative as opposed to competitive commercialization choice by small

1990; Henderson, 1993; Christensen, 1997).

${ }^{7}$ While “...the [stock market capitalization] value of the biotech industry is about $\$ 77 \mathrm{~B}$, and the value of Merck is $\$ 127 \mathrm{~B} \ldots$. [biotech has] 350 products in clinical trials whereas Merck has about 25... [At the same time] the biotech companies have roughly 20 times more drugs [than Merck] in late-stage, Phase III trials." (BioWorld, 1998, p. 3). 
firms. We focus on whether a start-up innovator who has successfully developed a potentially commercializable innovation cooperates or competes with a single incumbent. ${ }^{\text {a }}$ Consider a start-up innovator, $E$, who has developed a commercializable innovation. 6 then faces a choice of entering the product market by making those investments itself - the competitive strategy - or 'selling' the innovation to a single incumbent, $I$ - the cooperative strategy. The sale of the innovation itself may occur through a licensing agreement, a strategic alliance or outright acquisition of $E$ 's assets by I. Of course, these strategies are themselves differentiated in terms of their impact on future incentives to innovate and the locus of control over ultimate decisionmaking. However, the key, common feature of these cooperative strategies is that, if an agreement is reached, $I$ is able to foreclose on direct competition with $E$ in the product market, thereby achieving the monopoly profits associated with control over the prices of both old and new products.

While $E$ can exploit the innovation if it enters the product market, $I$ can only exploit the innovation if it contracts with $E$ or it replicates the innovation after $E$ 's disclosures during negotiations. To denote the difference in payoffs associated with incumbent control over the innovation, let $a=1$ if the incumbent controls the innovation (by contracting or replication) and 0 otherwise.

\footnotetext{
${ }^{8}$ While our model examines strategic interaction between a start-up innovator and a single incumbent, the underlying economic forces are more general and apply to an environment where a start-up innovator considers whether to enter the product market as an independent firm or whether to cooperate with one among a number of established firms. A more inclusive theoretical treatment would consider the possibility of non-exclusive cooperative behavior (e.g., through non-exclusive licensing), distinguish more carefully between different types of cooperative strategies (e.g., the distinction between licensing, strategic alliances, or outright acquisition), allow for imitation in the absence of negotiations, and consider the conduct between competing firms in the case of product market entry. Our simpler approach highlights the salient economic tradeoffs raised by the cooperation decision with unambiguous empirical predictions.

${ }^{9}$ A "commercializable" innovation is defined so that R\&D has resolved all of the technical uncertainties associated with the technology (i.e., there exists a working prototype technology) and so, with known
} 
In Table 2, we define the joint profits of $E$ and $I$ under the two alternative commercialization scenarios. Let $\pi^{m}(a)$ equal the level of monopoly profits that arise if $I$ does not face product market competition from $E$; either because they cooperate or entry is not profitable for $E . \pi_{I}^{c}($.$) and \pi_{E}^{c}($.$) represents the profits under competition between$ $I$ and $E$, respectively. In addition, if $E$ competes in the product market, $E$ must invest $K$ in "duplicative" commercialization assets already possessed by the incumbent. Investments which either firm must incur are incorporated into $\pi^{m}(1)$.

Table 2 distinguishes between environments by whether product market entry by $E$ is credible. When entry is not credible (that is, E's payoff under competition are less than $K)$, then $I$ continues to earn its pre-innovation monopoly profits $\left(\pi^{m}(0)\right)$ if a cooperative outcome is not reached. On the other hand, if entry is credible, entry results in duopoly (rather than monopoly) profits, the level and allocation of which depend on whether $I$ competes "head-to-head" with $E$ through imitation of the innovation as the result of disclosure during (failed) negotiations. Finally, if cooperation is achieved, the joint profits are equal to $\pi^{m}(1)$, the distribution of which depends on the relative bargaining power of $E$ and $I$. Let $\gamma$ equal the fraction of $\pi^{m}(1)$ that $E$ receives as the result of a Nash bargaining equilibrium between $E$ and $I$.

\section{Efficient Bargaining Equilibrium}

Our analysis begins under a scenario of efficient bargaining conditions - that is, so long as there are positive gains to trade between $I$ and $E$, we assume that an agreement is reached in equilibrium, and, moreover, $E$ faces no risk in pursuing negotiations (we 
incorporate various bargaining imperfections below). In other words, $E$ neither incurs fixed costs to begin bargaining nor weakens its potential competitive position as the result of disclosure during bargaining.

Under conditions of efficient bargaining, a cooperative outcome will be chosen whenever the industry profits from cooperation exceed those from competition, in which case $I$ must pay $E$ at least the amount that $E$ would earn under competition, $\pi_{E}^{c}(0)-K$. More precisely, we assume that $E$ and $I$ divide the surplus that remains after having compensated $E$ for forgoing this outside option.

In other words, in an environment where product market entry is not credible (i.e., $\left.\pi_{E}^{c}(0)<K\right), I$ continues to earn pre-innovation monopoly profits unless a cooperative agreement is reached. As such, cooperation occurs only if $\pi^{m}(1) \geq \pi^{m}(0)$ (i.e., the innovation adds value). On the other hand, when entry is credible (i.e., $\pi_{E}^{c}(0) \geq K$ ), cooperation ensures the continuation of monopoly profits, and so cooperation will be chosen so long as $\pi^{m}(1) \geq \pi_{E}^{c}(0)+\pi_{I}^{c}(0)-K$. As long as monopoly profits exceeds the sum of duopoly profits, this condition holds as long as $K$ is not too negative (i.e., $I$ does not face too heavy a cost disadvantage in commercializing the technology).

In sum, under efficient bargaining, there may be considerable gains from trade as the result of the preservation of monopoly profits and the avoidance of duplicative sunk

technology could be introduced into the product market.

${ }^{10}$ While it is possible to provide a full characterization of how the nature of bargaining affect the precise "price" at which cooperation takes place (see Gans and Stern (2000a)), the overall finding is that cooperation takes place when bargaining is efficient and industry profits are higher by the avoidance of competition is independent of the specific bargaining protocol.

${ }^{11}$ It is important to note that cooperation is therefore the equilibrium under the assumptions of the traditional R\&D strategic investment literature (Gilbert and Newbery, 1983; Reinganum, 1983; 1989). In other words, most prior theoretical work has simply assumed competition as an outcome rather than identifying the economic foundations of competition over cooperation. 
cost investment. With this in mind, we now incorporate two key bargaining imperfections arising from "search" costs prior to bargaining and the potential for expropriation during negotiations.

\section{Search Costs}

Even if IP rights are well defined, bargaining over "ideas" may involve search and transactional costs, $c$, borne by the entrant, which may reduce the gains from pursuing cooperation. For example, $I$ and $E$ may disagree about the commercial value of an innovation. Alternatively, $E$ may have to incur substantial costs in locating and identifying the "best" potential partner. In many industries, the competencies and costs of different incumbents may not be observable and so $E$ may have to exert effort in searching for a suitable partner.

Since $c$ is a sunk cost, it will not be recoverable during negotiations with $I$. Consequently, even if negotiations after search proceed "smoothly," $E$ accounts for this sunk cost (rather than the pure gains from cooperation) when choosing its optimal strategy. If entry is not credible, $E$ receives 0 if no agreement is reached while $I$ continues to earn its pre-innovation monopoly profits. In this case, $E$ expects to earn $\gamma\left(\pi^{m}(1)-\pi^{m}(0)\right)$ through bargaining and so will choose to cooperate so long as $\gamma\left(\pi^{m}(1)-\pi^{m}(0)\right)>c$. On the other hand, if entry is credible, $E$ earns $\pi_{E}^{c}(0)-K$ under competition while $I$ 's profits are equal to $\pi_{I}^{c}(0)$. This threat of competition affects the outside options of both parties in bargaining. Under Nash bargaining, the equilbrium 
alloation to $E$ will simply be equal to the outside option of $E$ plus $E$ 's share of the gains from cooperation: $\frac{12}{12}$

$$
\pi_{E}^{c}(0)-K+\gamma\left(\pi^{m}(1)-\left(\pi_{I}^{c}(0)+\pi_{E}^{c}(0)-K\right)\right)=\gamma\left(\pi^{m}(1)-\pi_{I}^{c}(0)\right)+(1-\gamma)\left(\pi_{E}^{c}(0)-K\right)
$$

Thus, $E$ cooperates so long as $\gamma\left(\pi^{m}(1)-\left(\pi_{I}^{c}(0)+\pi_{E}^{c}(0)-K\right)\right) \geq c$, suggesting that the probability of cooperation is declining in the expected search costs of the start-up innovator.

\section{Disclosure and Expropriation}

Perhaps a more fundamental source of bargaining imperfections in the context of R\&D licensing arises from the disclosure problem. As first articulated by Arrow (1962), the problem with a "market for ideas" is that while the value of an idea to a buyer cannot be known without the idea being disclosed, disclosure itself precludes the buyer from being required to pay for it. In the context of start-up innovator negotiations with $I$, when IP rights are weak, $E$ realizes that by disclosing the nature of the innovation during negotiations, it risks expropriation by $I$.

However, as first suggested by Anton and Yao (1994), expropriation may be partially mitigated by $E$ 's credible threat to compete with $I$ in the product market. Since start-up innovators are able to reduce incumbent rents even in the absence of IP rights, potential entrants may receive rents from cooperating because of their threat to compete.

We incorporate the impact of expropriation and its interaction with potential product market competition by assuming that, when $E$ negotiates with $I, I$ acquires the

\footnotetext{
${ }^{12}$ See Gans and Stern (2000a) for a detailed derivation of this bargaining solution.
} 
innovation with probability $1-\theta$. When copying occurs, $I$ can exploit the innovation with no payment. This lowers E's bargaining power since I's outside option has become more attractive $\left(\pi_{I}^{c}(1)>\pi_{I}^{c}(0)\right)$, and because its own outside option has become less attractive $\left(\pi_{E}^{c}(1)<\pi_{E}^{c}(0)\right)$. At the same time, with probability $\theta$, bargaining occurs according to the search cost equilibrium described above. Finally, it is important to recall that, if $E$ chooses to compete prior to bargaining at all, we assume that $I$ cannot imitate the innovation (i.e., $I$ earns $\pi_{I}^{c}(0)$ ).

E's optimal commercialization strategy depends on its expected outside options which depend on the credibility of product market entry. Three distinct cases arise, depending on whether entry is credible ex ante (prior to bargaining with $I$ ) or ex post (after bargagining and imitation by $I$ ) (see Table 3). In the first regime, the costs of commercialization are sufficiently high so that ex ante entry is not credible. In this case, ex post will also not be credible (i.e., $\pi_{E}^{c}(1)<\pi_{E}^{c}(0)<K$ ), and so the only route by which $E$ can earn a return on their innovation is to incur the search cost $c$ in exchange for an expected return of $\theta \gamma\left(\pi^{m}(1)-\pi^{m}(0)\right)$.

Second, it is possible that while ex ante entry is credible, ex post entry is not credible $\left(\pi_{E}^{c}(0) \geq K>\pi_{E}^{c}(1)\right)$. In this regime, $E$ risks "losing" its outside option if it attempts to cooperate with $I$ but is expropriated (at which point entry becomes noncredible). As such, E's expected benefits from pursuing a cooperative strategy are equal to $\theta\left(\gamma\left(\pi^{m}(1)-\pi_{I}^{c}(0)\right)+(1-\gamma)\left(\pi_{E}^{c}(0)-K\right)\right)-c$ which will be weighed against the benefits from competing in the product market, $\pi_{E}^{c}(0)-K$. 
Finally, if ex post entry is credible $\left(\pi_{E}^{c}(1) \geq K\right), E$ is able to credibly reduce $I$ 's monopoly rents under expropriation. Thus, $E$ will be able to earn a cooperative return from $I$ even when its innovation has been disclosed (Anton and Yao, 1995). Of course, as $E$ 's outside option is reduced and the post-disclosure bargaining surplus is smaller, this share is reduced to:

$$
\gamma\left(\pi^{m}(1)-\theta \pi_{I}^{c}(0)-(1-\theta) \pi_{I}^{c}(1)\right)+(1-\gamma)\left(\theta \pi_{E}^{c}(0)+(1-\theta) \pi_{E}^{c}(1)-K\right) .
$$

In summary, when choosing its commercialization strategy, $E$ will account for its share of the gains from avoiding competition and duplicative investment, while balancing these benefits with the costs of search and the potential losses in bargaining due to the disclosure hazard. The size of each of these effects depends critically upon the credibility of entry by $E$, both prior to bargaining as well as after an instance of expropriation (table 3 summarizes these equilibrium conditions).

\section{Comparative Statics and Hypothesis Formulation}

This simple model holds several potentially testable insights about the determinants of start-up commercialization strategy. First, strong intellectual property rights provide protection for smaller firms against imitation and expropriation by incumbents, hence raising the absolute level of their returns from innovation regardless of whether they choose to compete or cooperate. However, commercialization strategy depends on the relative returns to competition versus cooperation. In our model, the strength of intellectual property rights are reflected in the levels of $\theta$ or $\gamma$, since the former measures the probability that $E$ avoids expropriation while the latter reflects the ability of $I$ to work-around $E$ 's property protection and so reduce its bargaining power 
(Gans and Stern, 2000a). As either $\theta$ or $\gamma$ rises, the probability of cooperation rises, since stronger intellectual property protection improves $E$ 's ability to negotiate a larger share of the surplus from cooperation and hence makes it worthwhile to search for incumbent partners. Thus, strong intellectual property rights improve the returns from cooperation with more established firms at a faster rate than the returns to competition. Second, as the costs of searching for incumbent partners falls, $E$ becomes more likely to pursue a cooperative path. This is not surprising. Nonetheless, it does highlight the importance of controlling for differences in search costs in any empirical analysis. Finally, the comparative static of commercialization strategy with respect to $K$ is somewhat subtler. While decreases in the marginal value associated with investing $K$ will decrease the probability of competition among those firms who successfully introduce a product through competition or cooperation, increases in $K$ also weaken the start-up innovator's bargaining position and so increases in $K$ may result simply in non-commercialization of the innovation (i.e., the project would be technically but not economically feasible). However, within our empirical work, we condition our evaluation on a sample of firms among whom all have chosen to commercialize their innovation: under this sampling constraint, the return from cooperation rises at a slower rate than the return from competition as $K$ gets smaller. 


\section{Data}

\section{The Survey}

To evaluate whether the simple model of Section III helps explain start-up innovator commercialization strategy, we require project-level commercialization strategy and business environment data. To do so, we developed and administered a commercialization strategy to a sample of start-up innovators funded by two distinct sources: the US Small Business Innovative Research (SBIR) program and private venture capital. By dividing the sample between SBIR-funded firms and those funded by venture capital, we are able to incorporate variation in terms of the costs of identifying and contracting with potential partners while preserving the ability to test comparative statistics about the strength of intellectual property protection or the sunk costs associated with commercialization. As well, to ensure comparability across the two samples, we followed the procedure pursued by Lerner (1999) whereby we first collected a sample of SBIR-funded projects and then developed the venture-backed sample by matching on two characteristics: four digit SIC code and the firm sales level.

Before describing the summary statistics from the survey, it is useful to first describe some of the institutional detail associated with our two sources of data: SBIRfunded project and VC-backed entrepreneurial firms. The SBIR program is administered through the Small Business Association (SBA) and aimed at American firms with 500 or fewer employees (USGAO, 1995). Firms submit grant applications that are peerreviewed and awarded competitively according to three legislative goals: (a) to increase the rate of commercialization of innovations derived from Federal research, (b) to 
enhance the "competitiveness" of small firms in technology-intensive industries, and (c) to enhance the participation of small firms as well as women and minority-owned businesses in the Federal contracting process (USGAO, 1995)! 1314 Overall, once the awards are granted, the SBIR is a very "hands-off" subsidy in that the government neither takes over managerial control nor maintains an equity stake in funded organizations (Wallsten, 1998; Lerner, 1999). As well, because the program is administered through all Federal agencies who conduct R\&D, the SBIR tends to fund small-firm R\&D projects across a wide array of industries, particularly as compared to the concentrated nature of private venture financing (Gans and Stern, 2000b). However, to ensure comparability across our two samples, however, we analyze a sample drawn from five high-technology segments that have both SBIR as well as venture-backed firms.

The SBIR program can be contrasted with private venture capital. In contrast to the grants provided by the SBIR, VCs are allocated equity and managerial control in exchange for start-up capital. In addition to their purely financial role, VCs are believed to aid fledgling firms through providing superior management expertise to the firm as well as offering the VC firm's network of contacts and experience in corporate governance (Bygrave and Timmons, 1992; Roberts, 1991). While prior research has provided only limited direct empirical evidence of these non-investment roles for venture

\footnotetext{
${ }^{13}$ There are two rounds of potential awards. The maximum phase I award, earmarked for proof of concept and idea development, is $\$ 100,000$. For the period 1991-93, for all 11 participating federal agencies, the average ratio of funded Phase I proposals to proposals received was 13.3\% (USGAO, 1995). Phase II awards are capped at $\$ 750,000$ and is a grant for developing a technology and exploring its commercial potential. Only those firms with a Phase I award are considered for a Phase II award.

${ }^{14}$ The rationale for the program appears to be two-fold. First, small, entrepreneurial firms are thought to be highly productive in generating ideas and technical advances that become the basis for valuable innovations (Acs and Audretsch, 1988; Aghion and Tirole, 1994). Second, technology development in these firms is believed to generate positive externalities (Jaffe, 1986). Left on their own, these firms would likely underinvest relative to the socially optimal level due to their inability to appropriate the full value of their invention (Arrow, 1962).
} 
capitalists, both economists and organizational sociologists have increasingly explored such effect in recent years (Stuart, et al. 1999; Gompers and Lerner, 1999). More generally, while projects funded by the SBIR and VCs will differ in terms of the impact that the funders will have on the operation and strategy of the firm, projects funded by either source are comparable in several respects: the projects are selectively chosen, funded enterprises are often technology-based, funded organizations tend to be quite young, and the size of financing is comparable (by construction).

\section{Data and Summary Statistics}

Our data collection efforts took place in two stages. First, we collected information from a survey (Appendix C) administered to a sample of 100 SBIR-backed companies between January and March, 1999. The sample was drawn from the top 200 SBIR award winners between 1990 and 1993. To be included in the sample, firms had to have successfully commercialized an SBIR-funded project into the marketplace, either independently or through partnerships or cooperative agreement. While this requirement may have induced some degree of selectivity, this criterion was mostly in accord with our sampling criteria (i.e., most firms fit the criteria). We then assembled and similarly surveyed a sample of VC-funded companies in July, 1999, matched to the SBIR sample, based on four-digit industrial code and each firm's level of overall sales. ${ }^{15}$

\footnotetext{
${ }^{15}$ Companies were matched using a two-step procedure (following Lerner (1999)). First, we searched the Venture Economics database (through Security Data Corporation's Platinum Database) for candidate venture-backed companies whose primary line of business matched the four-digit SIC codes for the sample of SBIR-backed companies. We eliminated those companies that received SBIR funding (based on a database publicly available through the SBA web site). Finally, we consulted the Corptech Directory of Technology Companies (1998) to select only those firms within the four-digit SIC code that approximately matched the sales revenue of the SBIR sample, and surveyed those firms.
} 
The sample includes 55 VC-backed projects and 86 SBIR-backed projects, for a total of 141 projects whose primary focus is in one of five SIC codes 1 Two sectors are drawn from projects at the four digit SIC level: biotechnology and pre-packaged computer software. In addition, three sectors are drawn from projects at the two digit SIC level: industrial machinery \& equipment, electronic \& electrical equipment, and instruments (including medical devices). 17 Because 23 observations are missing information on complementary asset ratings, the final sample consists of 118 observations.

At the firm level, we collected background information on the organization's employees and promotion policies; financial information about corporate ownership, expenditures and revenues; and corporate governance issues. On the project level, each company was asked to provide information on the commercialization and financing history of the technology project, including revenues through sales and licensing of the technology, the importance of the technology in achieving various goals of the firm, key personnel involved in setting the commercialization strategy of the company, and information about the commercialization strategy itself. 18

Tables 4 and 5 report variable definitions and summary statistics. Our key dependent variable, COOPERATE, is a dummy variable equal to 1 if either the firm's revenues from the project are the result of licensing or intellectual property sales

\footnotetext{
${ }^{16}$ The overall response rate to the survey was approximately 50\%. Firms contacted but not responding seemed to be randomly mixed between firms not having a commercial product and those too busy or not willing to respond. Within the organization, the respondent was typically one of the following individuals: the director of $\mathrm{R} \& \mathrm{D}$, the director of sales or marketing, or the CEO. Most of the surveys (approximately $75 \%$ ) were filled out over the telephone, with the balance either faxed or mailed back.

${ }^{17}$ Analysis of a similar data set of 55 SBIR-backed firms matched with 55 comparable VC-backed firms yield qualitatively the same results as those presented in this paper.
} 
revenues or if the firm has been acquired since the project's development, and 0 otherwise. Within our sample of 118 projects, over one-third are commercialized through a cooperative strategy. However, as can be seen in Figure B, there is substantial heterogeneity across sectors in terms of this probability - while the probability of cooperation is more than $50 \%$ in biotechnology, only just over $20 \%$ of the projects are commercialized via a COOPERATE strategy in Industrial Equipment.

The main goal of our empirical exercise is to relate COOPERATE to variables proxying for the salience of intellectual property protection, the role of sunk cost asymmetries, and the costs of identifying and negotiating with potential partners. We now review our variables for each of these concepts in turn.

We measure the strength of intellectual property in several different ways across the sample. In the majority of our analysis, we focus on whether the start-up innovator has received at least one patent associated with the technology (PATENT THRESHOLD). While the mean number of patents held by each firm is a little greater than six (PATENTS), just less than two-thirds of the start-ups are associated with PATENT THRESHOLD $=1.19$ In addition to these "objective" measures of the association with intellectual property, we also exploit our survey to measure the perceived strength of appropriability (in the spirit of Levin et al. (1987)). Specifically, we asked each firm to rank several different appropriability strategies on a five-point Likert scale. In this regard, we use each firm's ranking of the importance of patents

\footnotetext{
18 Whenever possible, we used publicly available databases to verify information from the survey responders. For example, we verified the number of patents assigned to each organization through both the US Patent and Trademark Office's web site and the IBM patent database.

19 While earlier analyses have used patents in a limited way to evaluate commercialization strategy (Hellman and Puri (1998)), we interpret it according to a much more specific theory of how intellectual property shapes start-up innovator commercialization strategy.
} 
(PATENT LIKERT) as well as their maximal rating as to the importance of patent, patent litigation threats, or trade secrecy (IP LIKERT MAX).

To measure the relative investment costs that entrants face in acquiring complementary assets needed to commercialize their innovation, we again relied on a five point Likert scale. Executives from our sample companies were asked to rate the importance of control over each of the following in earning returns from their innovation: manufacturing, distribution channels, brand development, and servicing resources. We use this set of questions as a measure of the feasibility of entrants to acquire or control complementary assets necessary to exploit their invention, reasoning that executives would rate individual complementary assets as high if he or she believed the asset was obtainable at reasonable cost.

In the empirical analysis, we use two measures of investment costs to acquire complementary assets. CA LIKERT MAX is the maximum Likert score over a set of complementary assets necessary to commercialize a given innovation, an indication of whether any of the assets were important in earning returns from the technology-based project. Since complementary assets comprise a network of investment choices, all of which are important in the ultimate division of profits from innovation between entrants and incumbents (Teece, 1986), we use a second measure of complementary assets. CA LOW is a dummy variable set equal to one if CA LIKERT MAX is less than the maximum possible value of five. CA LOW is therefore an indicator of high relative investment cost for the entrant in acquiring the set of assets necessary to commercialize its innovation, a condition satisfied for just less than a third of our sample. 
As suggested earlier, we selected our sample so that it was approximately equally divided between SBIR-funded firms and VC-backed firms, thus allowing us to divide the sample between firms who on average would face relatively high versus relatively low costs in identifying and negotiating cooperative agreements with incumbent firms.

In addition, we include several firm-level and technology-level variables into our analysis. To control for differences across firms in their resources and capabilities, we include a control variable for the firm's initial size (a little over 25 employees on average) and whether the founder of the firm has remained the CEO (this latter effect captures the degree of agency in the firm in terms of the commercialization decision). Finally, we respondents recorded the type of innovation in order to control for both the innovation's quality and the degree to which the innovation would be complementary to the incumbent's current product set or whether this was more naturally a competitive product (e.g., almost $40 \%$ of the innovations were recorded as "novel systems"). With this data overview in mind, we now turn to our analysis of how start-up commercialization strategy is impacted by the economic environment.

\section{Empirical Results}

\section{Simple Correlations}

Our analysis begins in Tables 6 and 7 where we report the simple "pairwise" conditional means relating the probability that $\mathrm{COOP}=1$ to our key variables. The results are quite striking. For each of our measures of environmental variation in Table 6, the probability of cooperation is increasing at least $70 \%$ as one moves from the lower to 
higher conditional mean. As well, Table 7 presents how the probability of cooperation varies with PATENT THRESHOLD and CA LOW. When both of these measures are equal to zero, the probability of cooperation is less than $15 \%$; this percentage jumps to over $55 \%$ when both are equal to one. In other words, when there are fewer gains from trade (the start-up innovator rates control over assets as critical for profitability) and there are no well-defined intellectual property claims, then the probability of cooperation is much smaller than when these conditions are both reversed. Of course, these simple correlations are not in any sense dispositive, and so we now turn to a more systematic regression analysis to evaluate the robustness of these results.

\section{Regression Estimates}

Table 8 presents our core regression results, each of which is estimated using a binary probit model where the dependent variable is the probability of cooperation. In (8-1) through (8-3) we simply evaluate the pairwise interactions between each of our core measures and COOP; each is statistically significant and quantitatively important. As well, our results remain robust along each dimension when we include multiple measures as the same time, as we do in (8-4) through (8-6). For example, in our base regression model (Equation 8-6), an individual change in the three (indicator) variables at the means of the other independent variables changes the probability of cooperation $17.3 \%$ (VC), 18.4\% (CA LOW), and 23\% (PATENT THRESHOLD). In some sense, these "base" models simply confirm our results from Tables 5 and 6 about the basic relationship in the data between our core variables and COOP.

The statistical significance of CA LOW and PATENT THRESHOLD is robust to inclusion of a variety of control variables, a result demonstrated in Table 9. In this set of 
regressions, however, the significance of $\mathrm{VC}$ is weakened, with p-values ranging from $11-18 \%$. For example, our results are robust (except for the significance of the VC coefficient) to a regression that includes BASELINE EMPLOYEES as a control for the size of the organization at the start of the project. As well, this regression suggests that smaller organizations are more likely to choose to cooperate, perhaps in part due to capital constraints. In addition, (9-2) includes the CEO FOUNDER variable as a control for possible "founder" effects. There is evidence that firms headed by their founders may disproportionately prefer to retain corporate control over the commercialization process of their technology, even if it means (ex-post) less profits (Roberts, 1991). Finally, and perhaps most importantly, (9-3) suggests that both our findings for intellectual property and the role of sunk assets is robust to the inclusion of "industry" effects (for biotechnology and electronics), suggesting that we are identified both off the crossindustry and within-industry variation in our key measures. As well, notice that biotechnology firms in our sample are more likely to adopt a cooperator strategy in commercializing their innovations, a result which is consistent with industry-level analyses.

We interpret these results as providing support for a model in which an ideas market is enabled when a firm's business environment offers a strong intellectual property regime at the same time that entrant firms face high relative costs in acquiring and controlling key complementary assets necessary for commercialization success. In economic environments such as those often observed in the biotechnology industry, where patents are relatively effective in protecting intellectual property (Levin, et al., 1987) and firms face high relative investment costs (USOTA, 1984), firms tend to earn 
their returns from innovation through the ideas market, acting as an upstream supplier of "technology" rather than as a horizontal innovation-oriented competitor.

In contrast, when investment costs for the entrant are relatively low and the technological innovation is not protected by patents, as in our stylized example of the disk drive industry, we predict that the severe disclosure threat along with the relative high level of incompatibility between "generations" of technology forecloses the ideas market for entrants, who instead commercialize their innovations through product market competition; it is this market failure which then spurs the gale of creative destruction.

\section{Alternative Measures and Additional Controls}

In Table 10, we explore the robustness of our core results to different measures of complementary assets and intellectual property protection. In (10-1) through (10-3), we experiment with alternative measures of strength in the intellectual property regime. (PATENTS, PATENT LIKERT and IP LIKERT MAX). Each remains statistically significant and quantitatively important. While both PATENT THRESHOLD and PATENT LIKERT each have their own interpretational problems (e.g., PATENT THRESHOLD might be proxying for quality while it is difficult to ensure comparability from survey responses of this type), the robust relationship between each and COOP provides limited supporting evidence for one of our key hypotheses: stronger intellectual

\footnotetext{
${ }^{20}$ In addition to the tables reviewed in this section, Appendix A presents a single regression which simultaneously includes all of the control regressors discussed in this section, as well as several other variables which we experimented with extensively (and consistently found robustness to). Specifically, Appendix A includes controls for initial firm size, industrial sector, whether the CEO is the founder, the "type" of innovation, the composition of the firm's workforce in terms of the share of employees who have technical training or hold a $\mathrm{PhD}$, the length of development and the year of commercialization, the customer type, and the manufacturing process associated with the technology.
} 
property protection is associated with higher rather than lower levels of cooperation between incumbents and start-up innovator entrants.

These core results are also robust to an alternate measure of the complementary asset regime. CA LIKERT MAX, the maximum over the set of survey-collected Likert measures of the importance of complementary assets in earning returns from the firm's innovation, is also significant. Indeed, (10-5) shows that this variable is robust to industry and firm size effects. CA LIKERT MAX indicates that if any of the set of complementary assets is relatively costly for the entrant to acquire, the entrant is more likely to take a cooperative strategy, a result consistent with our preferred measure of complementary asset, CA LOW ${ }^{22}$ In addition, as previously mentioned, access to a network of assets is often necessary for commercial success. Therefore, a better measure of the complementary asset regime is the maximum value over the set of Likert ratings, a measure of whether any complementary assets are important in earning returns from commercializing an invention, and indeed, CA LIKERT MAX is significant in equation B-1.

In contrast to the systematic and robust results associated with intellectual property and sunk assets, our measure of search costs for alliance opportunities for entrants, $V C$, shows only weak robustness across different specifications, with p-values ranging between $5 \%$ and $12.9 \%$ across different tables. The weakness of this result may be an artifact of using the presence of venture capital financing as a measure of search costs incurred by start-ups in locating and striking a deal with interested product market

\footnotetext{
21 Recall that we interpret high ratings of the complementary asset variable as an indication that the manager believes the asset is attainable at a "reasonable" cost.
} 
incumbents. Due to heterogeneity in the information intermediation role among venture financiers, our measure of search costs is imperfect.

Finally, in Table 11, we show that not only are our core results robust to the inclusion of product characteristics, but these same features which are supposed to have explanatory power in the context of alternative models do not seem to have an effect in the data. Of course, we do not overemphasize such results as the type of innovation are self-reported by the organization. That said, our results concerning the principal elements of our theory (CA LOW, PATENT THRESHOLD, and VC) are indeed robust to the inclusion of such technology-type indicators.

\section{Conclusions}

Motivated by the substantial differences observed in start-up commercialization strategies across different high-technology sectors, this paper developed and tested a simple economic model identifying conditions under which start-up innovators earn their returns on innovation through product market cooperation with more established firms as opposed to competition with incumbents. The innovator's commercialization strategy choice weighs the competing benefits and costs of cooperation. While a cooperative commercialization strategy forestalls the costs of competition in the product market and avoids duplicative investment in sunk assets, imperfections in the "market for ideas" may lead innovators to instead pursue a competitive strategy in the product market. Specifically, if the transaction costs of bargaining with incumbents are high or if the

\footnotetext{
${ }^{22}$ As well, Appendix B shows that "individual" Likert ratings of the complementary asset regime are not significant. This result should not be surprising, as the importance of particular complementary assets for commercialization success vary (at least) across industries.
} 
innovator faces expropriation in the context of bargaining, then product market competition is more likely.

We tested these hypotheses using a novel sample of the start-up commercialization strategies of 118 companies. Overall, our empirical results provide evidence for the three main hypotheses associated with our theory. Perhaps most strikingly, firms who control intellectual property or are associated with venture capital financing are more likely to pursue a cooperative strategy. These results suggest that the role of intellectual property or venture capital on the competitiveness of product markets is somewhat more nuanced than assumed in many theoretical treatments. For example, while most prior work has emphasized the fact that strong intellectual property position increases the absolute returns to innovation, our evidence is consistent with a slightly more refined position - increases in the strength of intellectual property increase the relative returns to cooperation by facilitating the market for ideas.

Similarly, while most analyses simply assume that technology-oriented venture financing systematically spurs the "gale of creative destruction," our results are consistent with an alternative perspective. Specifically, while venture financing is certainly associated with certain "instances" of creative destruction, the focus by venture capitalists on profit maximization and their ability to reduce the costs of identifying potential partners increases the relative attractiveness of cooperation with more established firms on average. More generally, our results suggest that the pro-competitive benefits from start-up innovation reflect an earlier market failure - in the market for ideas.

Our findings suggest several directions for future research on how the strategic interaction between entrants and incumbents is mediated by the viability of the ideas 
market. First, we plan to deepen our understanding of the incentives associated with alternative commercialization strategies by both entrants and incumbents in "mixed" economic environments. For example, in environments where intellectual property is weak and a dominant incumbent would prefer to take advantage of the R\&D productivity of smaller firms, it is possible that there exists a motive to develop a reputation for "nonexpropriation" in order to provide incentives for innovation and cooperation with more established firms. 23

Second, we would like to evaluate the purely informational role played by venture capitalists. Specifically, after controlling for the ability of venture capitalists to simply identify "high-quality" projects, does association with a venture capitalist with greater access to potential partners (e.g., through participation on boards of directors) increase the performance and affect the commercialization strategy of start-up innovators?

Finally, it is important to recall that our data is composed of a sample of technologically successful start-up firms who made their initial investments during the first half of the 1990s. In some sense, then, these firms are representative of a wave of start-up investment that began during that time and has continued for at least a decade. As well, these firms chose their commercialization strategy in response to a changing environment that has tended to reinforce the strength of intellectual property and apply intellectual property protection in areas that once were poorly served. While earlier research has focused on the possibility that these two trends (venture financing and increases in the strength of intellectual property) may be associated with an increase in the economy wide rate of innovation or R\&D productivity (Kortum and Lerner, 1999), our results suggest that these institutional and environmental changes may also be

\footnotetext{
${ }^{23}$ Indeed, there is some evidence for such behavior by Intel in the microprocessor industry (Gawer, 2000).
} 
associated with a shift in the nature of strategic interaction between start-up innovators and established firms - from innovation competition to cooperation in the market for ideas. 


\section{References}

Acs, Z.J. and D.B. Audretsch (1988), "Innovation in Large and Small Firms: An Empirical Analysis," American Economic Review, Vol. 78, pp.678-690.

Aghion, P. and J. Tirole (1994), “The Management of Innovation,” Quarterly Journal of Economics, Vol. 109, pp.1185-1210.

Anton, J.J. and D. Yao (1994), "Expropriation and Inventions: Appropriable Rents in the Absence of Property Rights," American Economic Review, Vol. 84, pp.190-209.

Anton, J.J. and D. Yao (1995), "Start-ups, Spin-offs, and Internal Projects," Journal of Law Economics \& Organization, Vol. 11, pp.362-378.

Arora, A. (1995), "Licensing Tacit Knowledge: Intellectual Property Rights and the Market for Know-How," Economics of Innovation \& New Technology, Vol. 4, pp.41-59.

Arrow, K.J. (1962), "Economic Welfare and the Allocation of Resources for Inventions," in R. Nelson (ed.), The Rate and Direction of Inventive Activity: Economic and Social Factors, Princeton, N.J.: Princeton University Press.

BioWorld Publishing (1988), Biotechnology State of the Industry Report 1998, Atlanta, GA: BioWorld Publishing.

Bresnahan, T., Stern, S., and M. Trajtenberg (1997), Market Segmentation and the Sources of Rents from Innovation: Personal Computers in the late 1980s," RAND Journal of Economics, Vol. 0, Special Issue, pp.17-44.

Burt, R. (2000), "The Network Structure of Social Capital," forthcoming in R.I. Sutton and B.M. Staw (eds.), Research in Organizational Behavior, Greenwich, CT: JAI Press.

Bygrave, W. and J. Timmons (1992), Venture Capital at the Crossroads, Boston, MA: Harvard Business School Press.

Caves, R., Crookell, H. and J.P. Killing (1983), “The Imperfect Market for Technology Licenses." Oxford Bulletin of Economics and Statistics, Vol. 45, pp.249-67.

Chesbrough, H. and D. Teece (1996), "When Is Virtual Virtuous: Organizing for Innovation," Harvard Business Review, Vol. 74, pp.65-74.

Christensen, C.M. (1997), The Innovator's Dilemma: When New Technologies Cause Great Firms to Fail, Boston, MA: Harvard Business School Press. 
Cockburn, I. and R. Henderson (1994), "Racing to Invest? The Dynamics of Competition in Ethical Drug Discovery." Journal of Economics and Management Strategy, Vol. 3, pp.481-519.

Cohen, W. and R. Levin (1989), "Empirical Studies of Innovation and Market Structure," in R. Schmalensee and R. Willig (eds.), Handbook of Industrial Organization, Vol. 2, Amsterdam: North Holland, pp.1059-1107.

Corporate Technology Information Services, Inc. (1998), Corptech Directory of Technology Companies, $13^{\text {th }}$ Edition, Woburn, MA: Corporate Technology Information Services, Inc..

Dun \& Bradstreet, Inc. (1998), Industry Reference Handbook: Pharmaceuticals, Detroit, MI: Gale Press.

Foster, R.N. (1986), Innovation: The Attacker's Advantage, New York, NY: Summit Books.

Fosfuri, A., Arora, A., and A. Gambardella (1999), "Markets for Technology (Why do we see them, why don't we see more of them, and why should we care)," Universidad Carlos III, Working Paper No. 99-17(4).

Gallini, N. and R.A. Winter (1985), "Licensing in the Theory of Innovation," RAND Journal of Economics, Vol. 16, pp.237-52.

Gans, J.S. and S. Stern (2000a), "Incumbency and R\&D Incentives: Licensing the Gale of Creative Destruction," forthcoming in the Journal of Economics and Management Strategy.

Gans, J.S. and Stern (2000b) "When does Funding Small Firms Bear Fruit? Evidence from the SBIR Program," Working paper, MIT Sloan School of Management.

Gilbert, R. and D. Newbery (1982), "Preemptive Patenting and the Persistence of Monopoly," American Economic Review, Vol. 72, pp.514-526.

Gompers, P. and J. Lerner (1999), The Venture Capital Cycle, Cambridge, MA: MIT Press.

Green, J. and S. Scotchmer (1995), "On the Division of Profit in Sequential Innovation," RAND Journal of Economics, Vol. 26, pp.20-33.

Hellman, T. and M. Puri (1998), "The Interaction between Product Market and Financing Strategy: The Role of Venture Capital," Working Paper, Graduate School of Business, Stanford University. 
Henderson, R. and K. Clark (1990), "Architectural Innovation: The Reconfiguration of Existing Product Technologies and the Failure of Established Firms," Administrative Science Quarterly, Vol. 35, pp.9-30.

Henderson, R. (1993), "Underinvestment and Incompetence as Responses to Radical Innovation: Evidence from the Photolithographic Alignment Equipment Industry," RAND Journal of Economics, Vol. 24, pp.248-270.

Hobijn, B. and B. Jovanovic (1999), "The Information Technology Revolution and the Stock Market: Preliminary Evidence," Mimeo., New York University.

Jaffe, A. (1986), “Technological Opportunity and Spillovers of R \& D: Evidence from Firms' Patents, Profits, and Market Value," American Economic Review, Vol. 76, pp.984-1001.

James, B. (1977), The Future of the Multinational Pharmaceutical Industry to 1990, New York, NY: John Wiley.

Kamien, M. and N. Schwartz (1982), Market Structure and Innovation, Cambridge, UK: Cambridge University Press.

Katz, M.L. and c. ShapirO (1987), "R\&D Rivalry with Licensing or Imitation," American Economic Review, Vol. 77, pp.402-420.

Kortum, S. and J. Lerner (1998), "Does Venture Capital Spur Innovation?" National Bureau of Economic Research Working Paper, No. 6846.

Lerner, J. (1997), “An Empirical Analysis of a Technology Race," RAND Journal of Economics, Vol. 28, pp.228-247.

Lerner, J. and R. Merges (1998), "The Control of Strategic Alliances: An Empirical Analysis of the Biotechnology Industry," Journal of Industrial Economics, Vol. 46, pp.125-56.

Lerner, J. (1999), "The Government as Venture Capitalist: The Long-Run Impact of the SBIR Program," Journal of Business, Vol. 72, pp. 85-318.

Levin, R., Klevorick, A., Nelson, R. and S. Winter (1987), "Appropriating the Returns from Industrial R\&D,” Brookings Papers on Economic Activity.

Merges, R. (1992), "Uncertainty and the Standard of Patentability." High Technology Law Journal, Vol. 7, pp.1-70.

Merges, R. and R. Nelson (1990), "On the Complex Economics of Patent Scope." Columbia Law Review, Vol. 90, pp.839-916. 
Orsenegio, L. (1989), The Emergence of Biotechnology: Institutions and Markets in Industrial Innovation, New York, NY: St. Martin's Press.

Pisano, G.P. (1990), "The R\&D Boundaries of the Firm: An Empirical Analysis," Administrative Science Quarterly, Vol. 35, pp.153-176.

Pisano, G.P. (1991), "The Governance of Innovation: Vertical Integration and Collaborative Arrangements in the Biotechnology Industry," Research Policy, Vol. 20, pp.237-249.

Rausch, L. (1998), "Venture Capital Investment Trends in the United States and Europe," Issues Brief 99-303, Washington, D.C.: National Science Foundation.

Reinganum, J.F. (1983), "Uncertain Innovation and the Persistence of Monopoly," American Economic Review, Vol. 73, pp.741-748.

Reinganum, J.F. (1989), "On the Timing of Innovation," in R. Schmalansee and R.D. Willig (eds.), Handbook of Industrial Organization, Vol. 1, Amsterdam: North Holland, pp.849-908.

Roberts, E. (1991), Entrepreneurs in High Technology: Lessons from MIT and Beyond, Oxford, UK: Oxford University Press.

Salant, S. (1984), "Preemptive Patenting and the Persistence of Monopoly: Comment," American Economic Review, Vol. 74, pp.247-250.

Scherer, F.M. (1965), "Firm Size, Market Structure, Opportunity, and the Output of Patented Inventions," American Economic Review, Vol. 55, pp.1097-1125.

Scherer, F.M. (1992), "Schumpeter and Plausible Capitalism," Journal of Economic Literature, Vol. 30, pp.1416-1433.

Schumpeter, J. (1943), Capitalism, Socialism and Democracy, New York, NY: Harper \& Row.

Scotchmer, S. (1991), "Standing on the Shoulders of Giants: Cumulative Research and the Patent Law," Journal of Economic Perspectives Vol.5, pp.29-41.

Shan, W. (1990), "An Empirical Analysis of Organizational Strategies Used by Entrepreneurial High Technology Firms," Strategic Management Journal, Vol. 11, pp.129-139.

Strasser, F.(1999), “The New Entrepreneurs,” Business Week, December 6. 
Stuart, T., Hong, H. and R. Hybels (1999), "Interorganizational Endorsements and the Performance of Entrepreneurial Ventures," Administrative Science Quarterly, Vol. 44, pp.315-349.

Teece, D. (1986), "Profiting from Technological Innovation: Implications for Integration, Collaboration, Licensing and Public Policy," Research Policy, Vol. 15, pp.285305.

U.S. Congress, Office of Technology Assessment (USOTA) (1984), Commercial Biotechnology: An International Analysis, Washington, D.C.: Government Printing Office.

U.S. Government Accounting Office (USGAO) (1995), Federal Research: Interim Report on the Small Business Innovation Research Program, Washington, D.C.: USGAO.

U.S. Department of Justice (USDOJ) (1995), Licensing Guidelines, Washington, D.C.: USDOJ.

VentureOne, Inc. (2000), Venture Edge. San Francisco, CA, VentureOne Press.

Wallsten, S. (1998), "Rethinking the Small Business Innovation Research Program," in L. Branscomb and J. Keller (eds.), Investing in Innovation: Creating a Research and Innovation Program That Works, Cambridge, MA: MIT Press. 
TABLE 1

PHARMACEUTICAL FIRM MARKET LEADERSHIP

\begin{tabular}{|c|l|c|c|}
\hline $\begin{array}{c}\text { Sales Rank, } \\
\mathbf{1 9 9 7}\end{array}$ & \multicolumn{1}{|c|}{ Company } & Date Established & $\begin{array}{c}\text { Sales Rank, } \\
\mathbf{1 9 7 3}\end{array}$ \\
\hline \hline 1 & Merck & 17th century & 2 \\
\hline 2 & $\begin{array}{l}\text { Bristol-Myers } \\
\text { Squibb }\end{array}$ & 1887,1856 & 9 \\
\hline 3 & $\begin{array}{l}\text { American Home } \\
\text { Products }\end{array}$ & 1926 & 6 \\
\hline 4 & Pfizer & 1848 & 21 \\
\hline 5 & Abbott Labs & 1900 & 11 \\
\hline 6 & Eli Lilly & 1876 & 79 \\
\hline 7 & Warner Lambert & 1852 & 15 \\
\hline 8 & Baxter & 1931 & 31 \\
\hline 9 & Schering-Plough & 1851 & 7 \\
\hline 10 & $\begin{array}{l}\text { SmithKline } \\
\text { Beecham }\end{array}$ & 1830 & \\
\hline
\end{tabular}

Sources: Various corporate web sites; BioWorld 1998; Adams, 1977. 
TABLE 2

INDUSTRY PAYOFFS

\begin{tabular}{|c|c|c|}
\hline & Cooperate & Compete \\
\hline $\begin{array}{c}\text { Entry Credible } \\
\left(\pi_{E}^{c}(a) \geq K\right)\end{array}$ & $\pi^{m}(1)$ & $\pi_{E}^{c}(a)+\pi_{I}^{c}(a)-K$ \\
\hline $\begin{array}{c}\text { Entry Not Credible } \\
\left(\pi_{E}^{c}(a)<K\right)\end{array}$ & $\pi^{m}(1)$ & $\pi^{m}(0)$ \\
\hline
\end{tabular}

TABLE 3

\section{COMMERCIALIZATION STRATEGY EQUILIBRIUM}

\begin{tabular}{|c|c|}
\hline Credibility of Entry & Cooperate if \\
\hline $\begin{array}{c}\text { Ex Ante Entry Not Credible } \\
\left(\pi_{E}^{c}(0)<K\right)\end{array}$ & $\theta \gamma\left(\pi^{m}(1)-\pi^{m}(0)\right) \geq c$ \\
\hline $\begin{array}{c}\text { Ex Ante Entry Credible But Ex } \\
\text { Post not Credible }\end{array}$ & $\theta \gamma\left(\pi^{m}(1)-\pi_{I}^{c}(0)\right)$ \\
$\left(\pi_{E}^{c}(0) \geq K>\pi_{E}^{c}(1)\right)$ & $\geq c+(1-\theta(1-\gamma))\left(\pi_{E}^{c}(0)-K\right)$ \\
\hline $\begin{array}{c}\text { Ex Post Entry Credible } \\
\left(\pi_{E}^{c}(1) \geq K\right)\end{array}$ & $\gamma\left(\pi^{m}(1)-\theta \pi_{I}^{c}(0)-(1-\theta) \pi_{I}^{c}(1)\right)$ \\
& $\geq c+(1-(1-\gamma) \theta) \pi_{E}^{c}(0)-(1-\gamma)(1-\theta) \pi_{E}^{c}(1)-\gamma K$ \\
\hline
\end{tabular}


TABLE 4

VARIABLES \& DEFINITIONS

\begin{tabular}{|c|c|c|}
\hline VARIABLE & DEFINITION & SOURCE \\
\hline \multicolumn{3}{|c|}{ DEPENDENT VARIABLE: PROB. OF COOPERATION } \\
\hline COOPERATE & $\begin{array}{l}\text { Dummy = } 1 \text { if project revenues include } \\
\text { licensing revenues, intellectual property } \\
\text { sales, or merger and acquisition }\end{array}$ & MIT Survey \\
\hline \multicolumn{3}{|c|}{ APPROPRIABILITY MECHANISM VARIABLES } \\
\hline PATENTS & $\begin{array}{l}\text { Number of project patents awarded since } \\
\text { SBIR grant }\end{array}$ & $\begin{array}{l}\text { MIT Survey, } \\
\text { USPTO }\end{array}$ \\
\hline $\begin{array}{l}\text { PATENT } \\
\text { THRESHOLD }\end{array}$ & $\begin{array}{l}\text { Dummy }=1 \text { if the project has been awarded } \\
\text { at least one patent }\end{array}$ & $\begin{array}{l}\text { MIT Survey, } \\
\text { USPTO }\end{array}$ \\
\hline PATENT LIKERT & $\begin{array}{l}\text { 5-Point Likert scale rating of importance of } \\
\text { patents for appropriating returns }\end{array}$ & MIT Survey \\
\hline IP LIKERT MAX & $\begin{array}{l}\text { Maximum over the set of 5-point Likert } \\
\text { measures for the importance of } \\
\text { appropriability mechanisms in earning } \\
\text { returns from this project. }\end{array}$ & MIT Survey \\
\hline \multicolumn{3}{|c|}{ COMPLEMENTARY ASSET VARIABLES } \\
\hline $\begin{array}{l}\text { CA LIKERT } \\
\text { MAX }\end{array}$ & $\begin{array}{l}\text { Maximum over the set of 5-point Likert } \\
\text { measures for the importance of } \\
\text { complementary assets in earning returns } \\
\text { from this project. }\end{array}$ & MIT Survey \\
\hline CA LOW & $\begin{array}{l}\text { Dummy }=1 \text { if CA LIKERT MAX is less } \\
\text { than the maximum possible value of } 5\end{array}$ & MIT Survey \\
\hline \multicolumn{3}{|c|}{ FIRM-LEVEL VARIABLES } \\
\hline $\mathrm{VC}$ & $\begin{array}{l}\text { Dummy = } 1 \text { if the project is funded primarily } \\
\text { by venture capitalists }\end{array}$ & $\begin{array}{l}\text { MIT Survey, } \\
\text { Venture Economics }\end{array}$ \\
\hline $\begin{array}{l}\text { BASELINE } \\
\text { EMPLOYEES }\end{array}$ & $\begin{array}{l}\text { Number of employees at the start of the } \\
\text { project }\end{array}$ & MIT Survey \\
\hline CEO FOUNDER & $\begin{array}{l}\text { Dummy = } 1 \text { if the current CEO is a founder } \\
\text { of the firm }\end{array}$ & MIT Survey \\
\hline \multicolumn{3}{|c|}{ PRODUCT-LEVEL VARIABLES } \\
\hline $\begin{array}{l}\text { PRODUCT } \\
\text { INNOVATION }\end{array}$ & $\begin{array}{l}\text { Dummy }=1 \text { if the project is rated by } \\
\text { respondent as a product innovation }\end{array}$ & MIT Survey \\
\hline $\begin{array}{l}\text { PROCESS } \\
\text { INNOVATION }\end{array}$ & $\begin{array}{l}\text { Dummy }=1 \text { if the project is rated by } \\
\text { respondent as a process innovation }\end{array}$ & MIT Survey \\
\hline $\begin{array}{l}\text { STANDARD } \\
\text { SYSTEM } \\
\text { INNOVATION }\end{array}$ & $\begin{array}{l}\text { Dummy }=1 \text { if the project is rated by } \\
\text { respondent as innovation of novel } \\
\text { components within a relatively standard } \\
\text { system }\end{array}$ & MIT Survey \\
\hline $\begin{array}{l}\text { NOVEL SYSTEM } \\
\text { INNOVATION }\end{array}$ & $\begin{array}{l}\text { Dummy }=1 \text { if the project is rated by } \\
\text { respondent as innovation of a novel overall } \\
\text { system }\end{array}$ & MIT Survey \\
\hline
\end{tabular}


TABLE 5

MEANS \& STANDARD DEVIATIONS

$(\mathrm{N}=118)$

\begin{tabular}{|l|c|c|}
\hline VARIABLE & MEAN & STD. DEVIATION \\
\hline DEPENDENT VARIABLE: PROB. OF COOPERATION \\
\hline COOPERATE & 0.339 & 0.475 \\
\hline APPROPRIABILITY MECHANISM VARIABLES \\
\hline PATENTS & 6.678 & 14.189 \\
\hline PATENT THRESHOLD & 0.653 & 0.478 \\
\hline PATENT LIKERT & 3.475 & 1.478 \\
\hline IP LIKERT MAX & 3.534 & 1.460 \\
\hline COMPLEMENTARY ASSET VARIABLES & \\
\hline CA LIKERT MAX & 4.627 & 0.596 \\
\hline CA LOW & 0.322 & 0.469 \\
\hline FIRM-LEVEL VARIABLES & 0.466 & 0.501 \\
\hline VC & 25.481 & 43.662 \\
\hline BASELINE EMPLOYEES & 0.598 & 0.492 \\
\hline CEO FOUNDER & & \\
\hline PRODUCT-LEVEL VARIABLES & 0.678 & 0.469 \\
\hline PRODUCT INNOVATION & 0.331 & 0.472 \\
\hline PROCESS INNOVATION & 0.263 & 0.442 \\
\hline $\begin{array}{l}\text { STANDARD SYSTEM } \\
\text { INNOVATION }\end{array}$ & 0.373 & 0.486 \\
\hline $\begin{array}{l}\text { NOVEL SYSTEM } \\
\text { INNOVATION }\end{array}$ & \\
\hline
\end{tabular}


TABLE 6

PAIRWISE COOPERATION

CORRELATIONS

(Numbers in Cells Represent Probabilities)

\begin{tabular}{|c||c|c||c|c||c|c|}
\hline \multicolumn{1}{|c||}{} & \multicolumn{2}{c||}{$\begin{array}{c}\text { PATENT } \\
\text { THRESHOLD }\end{array}$} & \multicolumn{2}{c|}{ CA LOW } & \multicolumn{2}{c|}{ VC } \\
\hline & $=0$ & $=1$ & $=0$ & $=1$ & $=0$ & $=1$ \\
\hline COOP $=1$ & 0.21 & 0.38 & 0.27 & 0.47 & 0.25 & 0.44 \\
& & & & & & \\
\hline
\end{tabular}


TABLE 7

COOPERATION CONTINGENCY TABLE

\begin{tabular}{|c|c|c|c|}
\hline & & Int's Cost of Acquiring & Complementary Assets \\
\hline & & Relatively Low & Relatively High \\
\hline 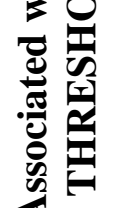 & 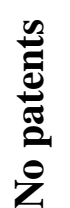 & $\begin{array}{c}\operatorname{Pr}(\text { Cooperate })=0.143 \\
(N=28)\end{array}$ & $\begin{array}{c}\operatorname{Pr}(\text { Cooperate })=0.308 \\
(N=13)\end{array}$ \\
\hline 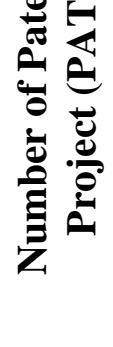 & 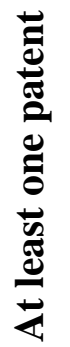 & $\begin{array}{c}\operatorname{Pr}(\text { Cooperate })=0.346 \\
(N=52)\end{array}$ & $\begin{array}{c}\operatorname{Pr}(\text { Cooperate })=0.560 \\
(N=25)\end{array}$ \\
\hline
\end{tabular}


TABLE 8

BASELINE COOPERATION

PROBIT REGRESSIONS

\begin{tabular}{|c|c|c|c|c|c|c|}
\hline & \multicolumn{6}{|c|}{$\begin{array}{c}\text { Dependent Variable }=\text { COOPERATE } \\
\text { N = } 118 \text { Observations }\end{array}$} \\
\hline & $\begin{array}{l}\text { (8-1) } \\
\text { Controlling for } \\
\text { CA LOW only }\end{array}$ & $\begin{array}{c}\mathbf{( 8 - 2 )} \\
\text { Controlling for } \\
\text { PATENT } \\
\text { THRESHOLD } \\
\text { only }\end{array}$ & $\begin{array}{l}\mathbf{( 8 - 3 )} \\
\text { Controlling } \\
\text { for VC } \\
\text { only }\end{array}$ & $\begin{array}{c}(\mathbf{8 - 4 )} \\
(7-1) \\
\text { combined } \\
\text { with (7-2) }\end{array}$ & $\begin{array}{c}(8-5) \\
(7-2) \\
\text { combined } \\
\text { with (7-3) }\end{array}$ & $\begin{array}{c}\mathbf{( 8 - 6 )} \\
\text { Base } \\
\text { regression } \\
\text { model }\end{array}$ \\
\hline CA LOW & $\begin{array}{c}0.532 \\
(0.253) \\
\end{array}$ & & & $\begin{array}{c}0.552 \\
(0.258) \\
\end{array}$ & & $\begin{array}{c}0.497 \\
(0.262) \\
\end{array}$ \\
\hline $\begin{array}{l}\text { PATENT } \\
\text { THRESHOLD }\end{array}$ & & $\begin{array}{c}0.646 \\
(0.267)\end{array}$ & & $\begin{array}{c}0.665 \\
(0.271)\end{array}$ & $\begin{array}{c}0.672 \\
(0.270)\end{array}$ & $\begin{array}{c}0.684 \\
(0.273)\end{array}$ \\
\hline$\overline{\mathrm{VC}}$ & & & $\begin{array}{c}0.502 \\
(0.241)\end{array}$ & & $\begin{array}{c}0.533 \\
(0.246)\end{array}$ & $\begin{array}{c}0.481 \\
(0.250)\end{array}$ \\
\hline CONSTANT & $\begin{array}{l}-\mathbf{0 . 5 9 8} \\
(0.150)\end{array}$ & $\begin{array}{l}-\mathbf{- 0 . 8 5 9} \\
(0.224)\end{array}$ & $\begin{array}{l}-\mathbf{- 0 . 6 6 2} \\
(0.171)\end{array}$ & $\begin{array}{l}-1.063 \\
(0.250)\end{array}$ & $\begin{array}{l}-1.136 \\
(0.263)\end{array}$ & $\begin{array}{l}-1.288 \\
(0.280)\end{array}$ \\
\hline Log Likelihood & -73.340 & -72.506 & -73.376 & -70.198 & -70.138 & -68.338 \\
\hline
\end{tabular}


TABLE 9

EXPLORING ROBUSTNESS

OF COOPERATION PROBITS

\begin{tabular}{|c|c|c|c|}
\hline & Depende & $\begin{array}{l}\text { nt Variable }=C C \\
N=118 \text { observat }\end{array}$ & $\begin{array}{l}\text { OPERATE } \\
\text { ons }\end{array}$ \\
\hline & $\begin{array}{c}\mathbf{( 9 - 1 )} \\
\text { Base } \\
\text { regression } \\
\text { controlling for } \\
\text { initial number } \\
\text { of employees }\end{array}$ & \begin{tabular}{|c|}
$\mathbf{( 9 - 2 )}$ \\
$(8-1)$ with \\
control for CEO \\
founder effects
\end{tabular} & $\begin{array}{c}\mathbf{( 9 - 3 )} \\
(8-1) \text { with sector } \\
\text { level controls }\end{array}$ \\
\hline CA LOW & $\begin{array}{c}0.618 \\
(0.273)\end{array}$ & $\begin{array}{c}0.573 \\
(0.277)\end{array}$ & $\begin{array}{c}0.559 \\
(0.282)\end{array}$ \\
\hline PATENT THRESHOLD & $\begin{array}{c}0.638 \\
(0.278)\end{array}$ & $\begin{array}{c}0.648 \\
(0.290)\end{array}$ & $\begin{array}{c}0.631 \\
(0.282)\end{array}$ \\
\hline $\mathrm{VC}$ & $\begin{array}{c}0.385 \\
(0.257)\end{array}$ & $\begin{array}{c}0.350 \\
(0.259)\end{array}$ & $\begin{array}{c}0.415 \\
(0.263)\end{array}$ \\
\hline BASELINE EMPLOYEES & $\begin{array}{c}0.004 \\
(0.003)\end{array}$ & $\begin{array}{c}0.004 \\
(0.003)\end{array}$ & $\begin{array}{c}0.004 \\
(0.003)\end{array}$ \\
\hline$\overline{\text { CEO FOUNDER }}$ & & $\begin{array}{l}-0.172 \\
(0.267)\end{array}$ & \\
\hline BIOTECH & & & $\begin{array}{c}0.658 \\
(0.376)\end{array}$ \\
\hline ELECTRONICS & & & $\begin{array}{l}-0.058 \\
(0.306)\end{array}$ \\
\hline CONSTANT & $\begin{array}{l}-2.154 \\
(0.652)\end{array}$ & $\begin{array}{l}-2.038 \\
(0.676)\end{array}$ & $\begin{array}{l}-2.068 \\
(0.673)\end{array}$ \\
\hline Log Likelihood & -66.137 & -64.985 & -64.316 \\
\hline
\end{tabular}


TABLE 10

EXPLORING ALTERNATIVE MEASURES

OF INTELLECTUAL PROPERTY \&

COMPLEMENTARY ASSETS

\begin{tabular}{|c|c|c|c|c|c|}
\hline & \multicolumn{5}{|c|}{$\begin{array}{c}\text { Dependent Variable }=\text { COOPERATE } \\
\mathbf{N}=118 \text { observations }\end{array}$} \\
\hline & \begin{tabular}{|c}
$\mathbf{( 1 0 - 1 )}$ \\
Patent counts \\
as measure of \\
appropriability \\
regime
\end{tabular} & \begin{tabular}{|c|}
$\mathbf{( 1 0 - 2 )}$ \\
Likert rating of \\
patent \\
importance as \\
measure of \\
appropriability \\
regime
\end{tabular} & \begin{tabular}{|c|}
$\mathbf{( 1 0 - 3 )}$ \\
Exploring \\
maximum over \\
likert ratings \\
of \\
appropriability
\end{tabular} & $\begin{array}{c}\text { (10-4) } \\
\text { Exploring } \\
\text { maximum over } \\
\text { likert ratings of } \\
\text { complementary } \\
\text { assets }\end{array}$ & $\begin{array}{c}\mathbf{( 1 0 - 5 )} \\
\text { (9-4) with } \\
\text { sector level } \\
\text { controls }\end{array}$ \\
\hline CA LOW & $\begin{array}{c}\mathbf{0 . 5 3 2} \\
(\mathbf{0 . 2 6 1})\end{array}$ & $\begin{array}{c}1.452 \\
(\mathbf{0 . 7 8 5})\end{array}$ & $\begin{array}{c}1.441 \\
(0.831)\end{array}$ & & \\
\hline CA LIKERT MAX & & & & $\begin{array}{l}-\mathbf{- 0 . 4 6 2} \\
(\mathbf{0 . 2 2 0})\end{array}$ & $\begin{array}{l}-\mathbf{- 0 . 4 3 0} \\
(\mathbf{0 . 2 2 9})\end{array}$ \\
\hline PATENTS & $\begin{array}{c}0.018 \\
(0.010)\end{array}$ & & & & \\
\hline \begin{tabular}{|l} 
PATENT \\
THRESHOLD
\end{tabular} & & & & $\begin{array}{c}\mathbf{0 . 5 9 8} \\
(\mathbf{0 . 2 7 7}) \\
\end{array}$ & $\begin{array}{c}0.593 \\
(0.281)\end{array}$ \\
\hline PATENT LIKERT & & $\begin{array}{c}\mathbf{0 . 2 0 8} \\
(\mathbf{0 . 1 0 3})\end{array}$ & & & \\
\hline IP LIKERT MAX & & & $\begin{array}{c}\mathbf{0 . 2 2 7} \\
(\mathbf{0 . 1 0 7})\end{array}$ & & \\
\hline $\begin{array}{l}\text { CA LOW * } \\
\text { PATENT LIKERT }\end{array}$ & & $\begin{array}{l}-0.275 \\
(0.199)\end{array}$ & & & \\
\hline $\begin{array}{l}\text { CA LOW * IP LIKERT } \\
\text { MAX }\end{array}$ & & & $\begin{array}{l}-0.270 \\
(0.206)\end{array}$ & & \\
\hline $\mathrm{VC}$ & $\begin{array}{c}0.385 \\
(0.249) \\
\end{array}$ & $\begin{array}{c}\mathbf{0 . 4 8 7} \\
(\mathbf{0 . 2 4 9}) \\
\end{array}$ & $\begin{array}{c}\mathbf{0 . 4 9 0} \\
(\mathbf{0 . 2 4 9}) \\
\end{array}$ & $\begin{array}{c}0.391 \\
(0.257) \\
\end{array}$ & $\begin{array}{c}0.422 \\
(0.262) \\
\end{array}$ \\
\hline \begin{tabular}{|l|} 
BASELINE \\
EMPLOYEES
\end{tabular} & & & & $\begin{array}{c}0.004 \\
(0.003)\end{array}$ & $\begin{array}{c}0.004 \\
(0.003)\end{array}$ \\
\hline BIOTECH & & & & & $\begin{array}{c}\mathbf{0 . 6 6 7} \\
(\mathbf{0 . 3 7 6})\end{array}$ \\
\hline ELECTRONICS & & & & & $\begin{array}{l}-0.089 \\
(0.311)\end{array}$ \\
\hline CONSTANT & $\begin{array}{l}-\mathbf{- 0 . 9 0 4} \\
(0.198) \\
\end{array}$ & $\begin{array}{l}-1.537 \\
(0.420)\end{array}$ & $\begin{array}{l}-1.613 \\
(0.437)\end{array}$ & $\begin{array}{c}0.141 \\
(1.059)\end{array}$ & $\begin{array}{c}0.088 \\
(1.158)\end{array}$ \\
\hline Log Likelihood & -69.785 & -69.429 & -69.208 & -66.475 & -64.519 \\
\hline
\end{tabular}


TABLE 11

EXPLORING TECHNOLOGICAL INNOVATION EFFECTS

\begin{tabular}{|c|c|c|c|c|}
\hline & \multicolumn{4}{|c|}{$\begin{array}{l}\text { Dependent Variable = COOPERATE } \\
\text { N = } 118 \text { observations }\end{array}$} \\
\hline & $\begin{array}{c}\text { (11-1) } \\
\text { Exploring } \\
\text { importance of } \\
\text { product } \\
\text { innovation }\end{array}$ & $\begin{array}{c}\text { (11-2) } \\
\text { Exploring } \\
\text { importance of } \\
\text { process } \\
\text { innovation }\end{array}$ & $\begin{array}{c}\mathbf{( 1 1 - 3 )} \\
\text { Exploring } \\
\text { importance of } \\
\text { component } \\
\text { innovation }\end{array}$ & $\begin{array}{c}\mathbf{( 1 1 - 4 )} \\
\text { Exploring } \\
\text { importance of } \\
\text { radical } \\
\text { innovation }\end{array}$ \\
\hline CA LOW & $\begin{array}{c}0.492 \\
(0.263)\end{array}$ & $\begin{array}{c}0.501 \\
(0.265)\end{array}$ & $\begin{array}{c}0.481 \\
(0.270)\end{array}$ & $\begin{array}{c}0.491 \\
(0.263)\end{array}$ \\
\hline PATENT THRESHOLD & $\begin{array}{c}0.683 \\
(0.273)\end{array}$ & $\begin{array}{c}0.684 \\
(0.273)\end{array}$ & $\begin{array}{c}0.669 \\
(0.278)\end{array}$ & $\begin{array}{c}0.693 \\
(0.274)\end{array}$ \\
\hline $\mathrm{VC}$ & $\begin{array}{c}0.480 \\
(0.250)\end{array}$ & $\begin{array}{c}0.477 \\
(0.253)\end{array}$ & $\begin{array}{c}0.482 \\
(0.250)\end{array}$ & $\begin{array}{c}0.476 \\
(0.250)\end{array}$ \\
\hline PRODUCT INNOVATION & $\begin{array}{l}-0.052 \\
(0.267)\end{array}$ & & & \\
\hline PROCESS INNOVATION & & $\begin{array}{l}-0.023 \\
(0.274)\end{array}$ & & \\
\hline $\begin{array}{l}\text { STANDARD SYSTEM } \\
\text { INNOVATION }\end{array}$ & & & $\begin{array}{c}0.076 \\
(0.293)\end{array}$ & \\
\hline $\begin{array}{l}\text { NOVEL SYSTEM } \\
\text { INNOVATION }\end{array}$ & & & & $\begin{array}{l}-0.089 \\
(0.259)\end{array}$ \\
\hline CONSTANT & $\begin{array}{l}-1.250 \\
(0.340)\end{array}$ & $\begin{array}{l}-1.280 \\
(0.295)\end{array}$ & $\begin{array}{l}-1.293 \\
(0.280)\end{array}$ & $\begin{array}{l}-1.256 \\
(0.294)\end{array}$ \\
\hline Log Likelihood & -68.319 & -68.334 & -68.305 & -68.279 \\
\hline
\end{tabular}


Figure A. Leadership of Entrant Firms in the Hard Disk Drive Sector
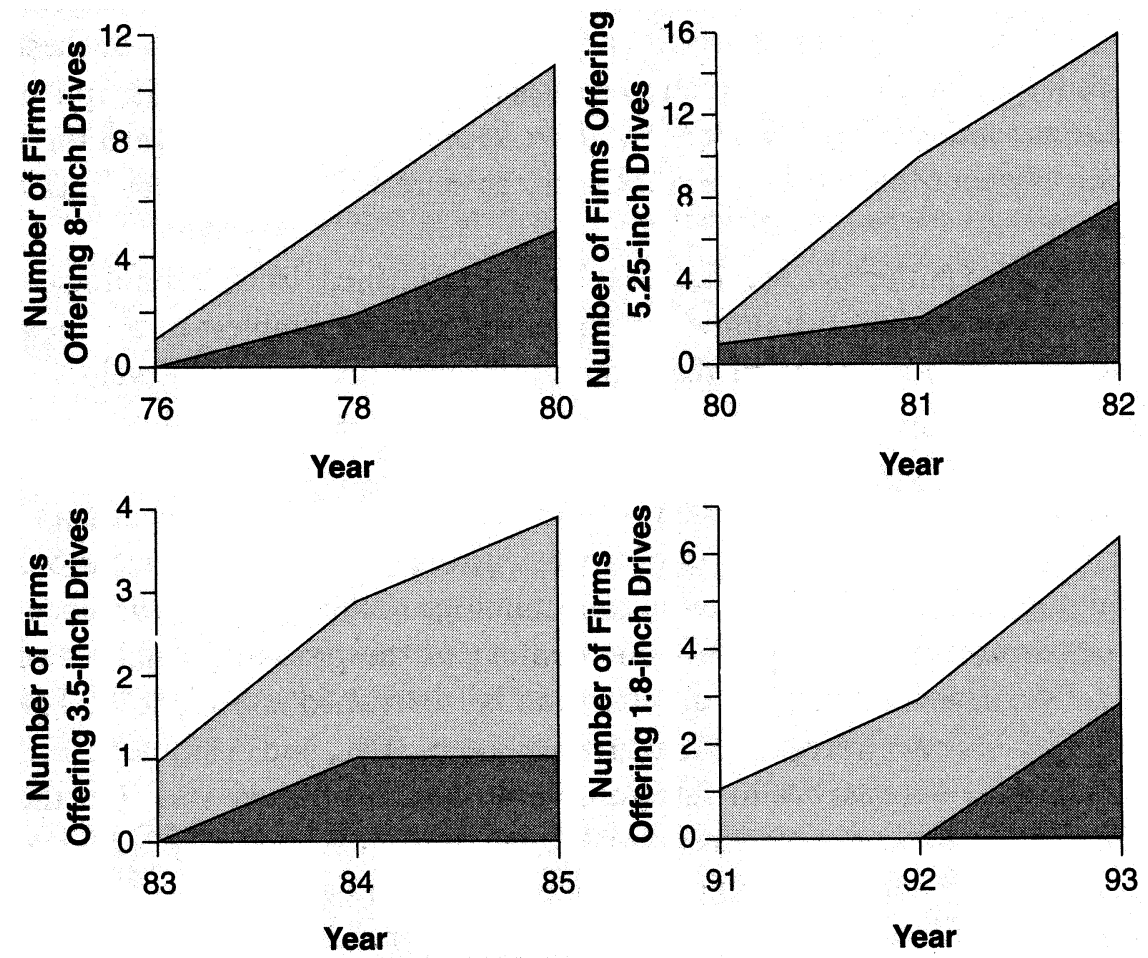

$\square$ Entrant Firms
Established Firms

Source: Christensen (1997), p. 23. 
Figure B: Probability of Cooperation by Industrial Segment

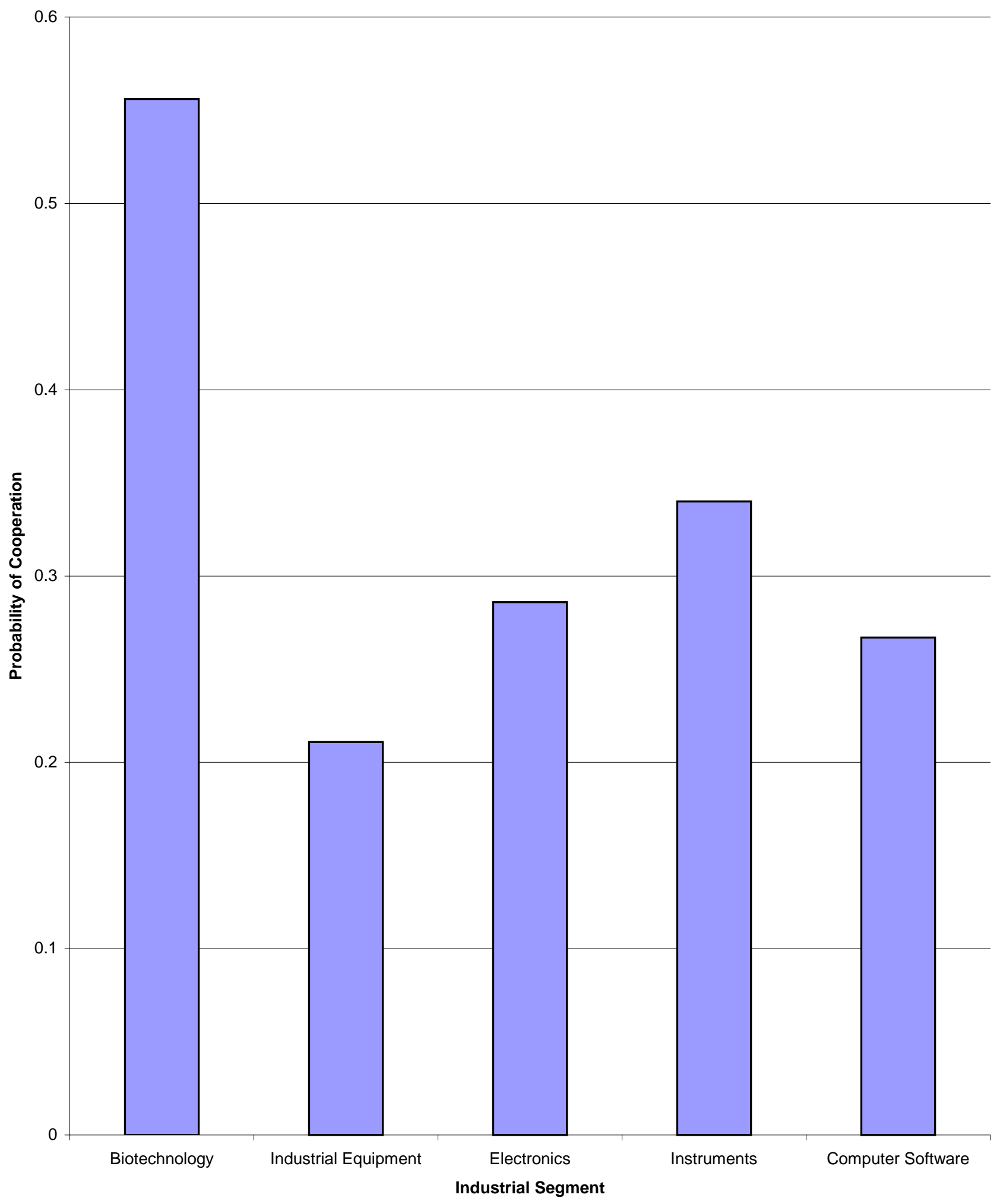


APPENDIX A

SIMULTANEOUS INCLUSION OF ALL CONTROL VARIABLES

Dependent Variable $=$ COOPERATE $(\mathbf{N}=118)$

CORE EFFECTS

\begin{tabular}{|c|c|}
\hline CA LOW & $\begin{array}{c}0.628 \\
(0.314)\end{array}$ \\
\hline PATENT THRESHOLD & $\begin{array}{c}0.660 \\
(0.322) \\
\end{array}$ \\
\hline $\mathrm{VC}$ & $\begin{array}{c}0.668 \\
(0.340)\end{array}$ \\
\hline \multicolumn{2}{|l|}{ FIRM EFFECTS } \\
\hline BASELINE EMPLOYEES & $\begin{array}{c}0.004 \\
(0.004) \\
\end{array}$ \\
\hline CEO FOUNDER & $\begin{array}{l}-0.186 \\
(0.290)\end{array}$ \\
\hline$\%$ EMPLOYEES PHD & $\begin{array}{c}0.014 \\
(0.011) \\
\end{array}$ \\
\hline $\begin{array}{l}\text { \% EMPLOYEES WITH ENGINEERING } \\
\text { BKGD. }\end{array}$ & $\begin{array}{l}-0.005 \\
(0.006)\end{array}$ \\
\hline \multicolumn{2}{|l|}{ INDUSTRY EFFECTS } \\
\hline BIOTECH & $\begin{array}{c}0.982 \\
(0.595) \\
\end{array}$ \\
\hline ELECTRONIC EQPT. & $\begin{array}{l}-0.053 \\
(0.345)\end{array}$ \\
\hline \multicolumn{2}{|l|}{ INNOVATION TYPE } \\
\hline \begin{tabular}{|l} 
PRODUCT INNOVATION \\
\end{tabular} & $\begin{array}{c}0.102 \\
(0.319) \\
\end{array}$ \\
\hline PROCESS INNOVATION & $\begin{array}{c}0.010 \\
(0.312) \\
\end{array}$ \\
\hline STANDARD SYSTEM INNOVATION & $\begin{array}{c}0.208 \\
(0.338)\end{array}$ \\
\hline $\begin{array}{l}\text { NOVEL SYSTEM } \\
\text { INNOVATION }\end{array}$ & $\begin{array}{l}-0.193 \\
(0.313) \\
\end{array}$ \\
\hline \multicolumn{2}{|l|}{ TYPE OF MANUFACTURING } \\
\hline MADE-TO-ORDER & $\begin{array}{c}0.315 \\
(0.284) \\
\end{array}$ \\
\hline MASS PRODUCTION & $\begin{array}{l}-0.076 \\
(0.293) \\
\end{array}$ \\
\hline \multicolumn{2}{|l|}{ INNOVATION TIMING } \\
\hline YEAR OF INTRODUCTION & $\begin{array}{c}0.011 \\
(0.007) \\
\end{array}$ \\
\hline TIME-TO-MARKET & $\begin{array}{l}-0.0003 \\
(0.003)\end{array}$ \\
\hline \multicolumn{2}{|l|}{ CUSTOMER TYPE } \\
\hline 10-100 CUSTOMERS & $\begin{array}{l}-0.560 \\
(0.523)\end{array}$ \\
\hline 100-500 CUSTOMERS & $\begin{array}{l}-0.220 \\
(0.544)\end{array}$ \\
\hline > 500 CUSTOMERS & $\begin{array}{l}-0.463 \\
(0.590)\end{array}$ \\
\hline CONSTANT & $\begin{array}{l}-3.186 \\
(1.183)\end{array}$ \\
\hline Log Likelihood & -59.681 \\
\hline
\end{tabular}




\section{APPENDIX B}

INDIVIDUAL MEASURES OF

COMPLEMENTARY ASSETS

\begin{tabular}{|c|c|c|c|c|c|}
\hline & \multicolumn{5}{|c|}{$\begin{array}{c}\text { Dependent Variable }=\text { COOPERATE } \\
\text { N = } 118 \text { observations }\end{array}$} \\
\hline & $\begin{array}{c}\text { (B-1) } \\
\text { Maximum } \\
\text { over CA } \\
\text { variables as } \\
\text { regressor }\end{array}$ & \begin{tabular}{|c} 
(B-2) \\
Importance of \\
control over \\
manufacturing \\
in earning \\
returns
\end{tabular} & \begin{tabular}{|c|} 
(B-3) \\
Importance of \\
control over \\
distribution \\
channels in \\
earning \\
returns
\end{tabular} & \begin{tabular}{|c|} 
(B-4) \\
Importance of \\
control over \\
branding in \\
earning returns
\end{tabular} & $\begin{array}{c}\text { (B-5) } \\
\text { Importance of } \\
\text { control over } \\
\text { servicing } \\
\text { resources in } \\
\text { earning returns }\end{array}$ \\
\hline CA LIKERT MAX & $\begin{array}{l}-0.328 \\
(0.202)\end{array}$ & & & & \\
\hline $\begin{array}{l}\text { CA LIKERT } \\
\text { MANUFACTURING }\end{array}$ & & $\begin{array}{l}-0.053 \\
(0.092)\end{array}$ & & & \\
\hline $\begin{array}{l}\text { CA LIKERT } \\
\text { DISTRIBUTION }\end{array}$ & & & $\begin{array}{l}-0.071 \\
(0.094)\end{array}$ & & \\
\hline $\begin{array}{l}\text { CA LIKERT } \\
\text { BRAND }\end{array}$ & & & & $\begin{array}{c}0.078 \\
(0.093)\end{array}$ & \\
\hline $\begin{array}{l}\text { CA LIKERT } \\
\text { SERVICE }\end{array}$ & & & & & $\begin{array}{c}0.070 \\
(0.100)\end{array}$ \\
\hline $\begin{array}{l}\text { PATENT } \\
\text { THRESHOLD }\end{array}$ & $\begin{array}{c}0.651 \\
(0.272)\end{array}$ & $\begin{array}{c}0.679 \\
(0.270)\end{array}$ & $\begin{array}{c}0.676 \\
(0.269)\end{array}$ & $\begin{array}{c}0.656 \\
(0.271)\end{array}$ & $\begin{array}{c}0.695 \\
(0.273)\end{array}$ \\
\hline $\mathrm{VC}$ & $\begin{array}{c}0.497 \\
(0.249) \\
\end{array}$ & $\begin{array}{c}0.518 \\
(0.248) \\
\end{array}$ & $\begin{array}{c}0.506 \\
(0.249) \\
\end{array}$ & $\begin{array}{c}0.516 \\
(0.248) \\
\end{array}$ & $\begin{array}{c}0.524 \\
(0.247) \\
\end{array}$ \\
\hline CONSTANT & $\begin{array}{c}0.409 \\
(0.982) \\
\end{array}$ & $\begin{array}{l}-0.930 \\
(0.440)\end{array}$ & $\begin{array}{l}-0.891 \\
(0.412)\end{array}$ & $\begin{array}{l}-1.371 \\
(0.399)\end{array}$ & $\begin{array}{l}-1.396 \\
(0.458)\end{array}$ \\
\hline Log Likelihood & -68.824 & -69.971 & -69.851 & -69.133 & -69.889 \\
\hline
\end{tabular}




\title{
APPENDIX C: MIT SLOAN SCHOOL COMMERCIALIZATION STRATEGIES SURVEY
}

\author{
Principal Investigator: Professor Scott Stern, MIT Sloan School \& NBER \\ Researcher: David Hsu, MIT; Joshua Gans, University of Melbourne
}

The goal of this project is to evaluate how companies commercialize innovative new technologies. We are exploring different commercialization strategies and how success at a technical level affects firm strategy.

Enclosed is a survey, which asks you to describe the circumstances surrounding a specific innovative project or initiative. We would like to focus on your firm's involvement in its main business area. Within that frame, please choose a research and/or development project which is internally perceived as an important source of value for your firm. We would like you to choose a project which provided direct financial returns for the firm, through direct sales, licensing agreements, or in strengthening the bargaining position of the firm.

Once the project is chosen, the survey is divided into two parts:

- $\quad$ General background of your company

- Commercialization history of the innovation

Participation in this study is entirely voluntary, and you can decline to answer any questions or decline further participation at any time. The survey should take no more than 25 minutes to complete. Responses will be kept both confidential and anonymous. Please return this survey and direct inquiries to:

Professor Scott Stern

MIT Sloan School

E52-554

Cambridge, MA 02142

TEL: $617-253-5219$

FAX: 617-253-2660

e-mail: sstern@mit.edu

Thank you for your participation! 


\section{MIT SLOAN SCHOOL \\ COMMERCIALIZATION STRATEGIES SURVEY}

Name of Firm:

Year Founded: 19

Part I: Background Information

A. Employee Information

\# of Employees: At the start of chosen project

Currently

What share of employees hold as their highest degree: BA/BS

$\%$

Master's $\%$

$\%$

What share of employees have backgrounds in:

Engineering Science

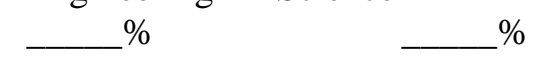

Is there a management track for technically trained employees?

Are senior managers promoted from within the firm?

$\begin{array}{ll}\square \text { Yes } & \square \text { No } \\ \square \text { Yes } & \square \text { No }\end{array}$

Please rank the relative importance of the following factors in determining the promotion of scientists \& engineers (with $1=$ most important $-4=$ least important):

External research reputation

Demonstrated contribution to R\&D teams

Demonstrated contribution to cross-functional teams

Management ability

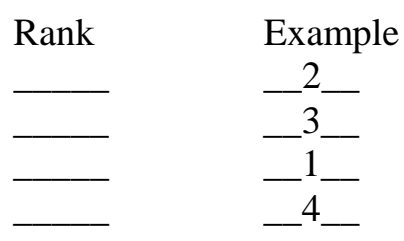

B. Financial Information

What is the percentage of corporate ownership held by the following groups:

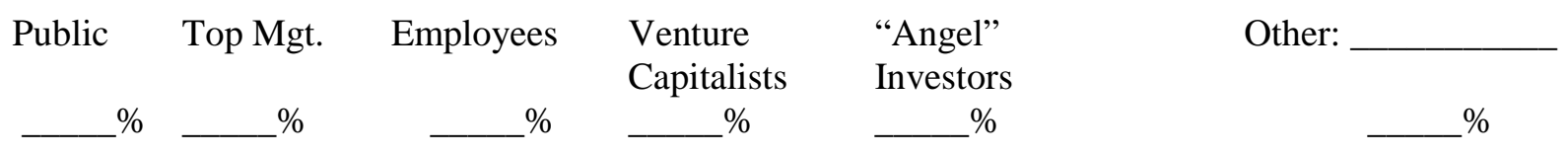

What mechanisms are used to fund new technology development or R\&D projects (check all that apply):

$\square$ Internal Cash $\quad \square$ Loans $\quad \square$ Contract Research

$\square$ Partnering w/ Suppliers $\quad \square$ Partnering w/ Customers $\quad \square$ Other:

What is the percentage of gross revenues devoted towards:

R\&D New Product Marketing

$\%$ 
Total sales for your company: When the project was initiated In 1998

$\$$

$\$$

C. Organizational Governance \& Structure

\# of Directors:

What share of directors are:

\begin{tabular}{rr} 
Internal & External \\
\hline & $\%$
\end{tabular}

Venture Capital Appointed $\%$

Which characteristics in the first column apply to the following executives?

Firm founder

CEO

President

R\&D or Technology

Promoted from within

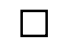

$\square$

Director

Hired externally

Has run other companies

How many distinct products does your firm develop?

How many alliances has your company entered into with another firm?

What were the nature of these alliances?

$\square$ Manufacturing

$\square$ Research \& Development

$\square$ Sales/Marketing

$\square$ Product Development

$\square$ Distribution

Has your firm entered into any licensing deals? $\square$ Yes: licensed-out $\quad \square$ Yes: licensed-in $\quad \square$ No

If your firm has licensed-out, what were the total licensing revenues? 1998 \$

Total \$
What were the terms?
$\square$ Exclusive
Non-Exclusive

Who were the licensees? (mark all that apply)

$\square$ Product Market Incumbents

$\square$ Product Market Entrants

$\square$ Government Agencies

$\square$ Non-market agents (e.g., universities)

\section{Part II: Commercialization History of Chosen Project}

Name of technology/product:

Brief description of the technology:

Was this technology originated from research and development performed at your firm? $\quad \square$ Yes $\square$ No

If the technology did not originate from your firm, where did it come from? $\square$ Licensed from parent firm $\square$ Licensed from university $\quad \square$ Licensed from corporate lab

$\square$ Other: 
Number of patents issued directly related to this technology:

Number of patents issued to your organization since founding:

Please check the terms which best describe this technology:

$\square$ Assembled

$\square$ Non-Assembled

Please check the terms which best describe the innovation (check all that apply):

$\square$ Product Innovation

$\square$ Process Innovation

$\square$ Novel components within a relatively standard system

$\square$ Novel overall system

What year was the product's first commercial introduction?

19

Time from conception of technology to first prototype:

months

Time from prototype to first sale:

months

Financing history of this project:

Year

Source

Amount

For this project, what activities did the following actors facilitate?

Locating key personnel such as

venture angel

capitalist

investor

managers and technologists

Locating sources of additional capital

Gaining access to critical technologies

Increasing the firm's focus on a small

number of projects, technologies,

or markets

Locating and arranging introductions

with potential alliance partners

Participating in discussions over licensing and commericalization strategies Other (specify) 
What are the sources of revenue (on a percentage basis) associated with this technology?

Sales $\%$
Licensing Revenue $\%$
Intellectual Property

Asset Sale

$\%$

Share of revenues of this project from government contracts: $\%$

What is the number of distinct customers for this project?:

$\square<10$

$\square 10-100$

$101-500$

$>500$

Form of sales (check all that apply):

$\square$ made to order

Total sales of the product

Sales attributable to this product in 1998 ?

Sales attributable to this product since the inception of this project?

$\$$

$\$$

Has your firm been acquired since the development of this technology?

$\square$ Yes $\square$ No

If so, by whom?

Does the new firm (after the merger) have more than 500 employees? $\square$ Yes $\quad \square$ No

Why did your company decide to undergo an acquisition?

Has the product been substantially modified/upgraded since development of the first working prototype?

$\square$ No $\square$ Yes; If yes, please describe the modifications:

If this technology resulted in licensing revenues,

What was the first year in which the technology was licensed?

What was the licensing revenue? 1998 \$

What were the terms? $\square$ Exclusive

Were other technologies bundled in the license? $\square$ Yes

19

Total \$

$\square$ Non-Exclusive

$\square$ No

Who were the licensees? (mark all that apply)

$\square$ Product Market Incumbents

$\square$ Product Market Entrants

$\square$ Government Agencies

Non-market agents (e.g., universities)

Why did your company decide to license-out this technology?

Please rate the importance of the strategic goals this technology enabled for your company:

Attraction of venture capital or outside funding

LOW

HIGH

N/A $\quad 1 \quad 2 \quad 3 \quad 4 \quad 4 \quad 5$


Attraction of scientists or other employees

$\begin{array}{llllll}\text { N/A } & 1 & 2 & 3 & 4 & 5 \\ \text { N/A } & 1 & 2 & 3 & 4 & 5 \\ \text { N/A } & 1 & 2 & 3 & 4 & 5 \\ \text { N/A } & 1 & 2 & 3 & 4 & 5\end{array}$

Enable further government grants

Provided visibility of the company to customers or suppliers

Was an important factor for the firm getting acquired

Who were the key personnel involved in formulating the commercialization strategy for this product?

$\square$ CEO $\quad \square$ Technology/R\&D Manager $\quad \square$ Marketing and sales manager

You mentioned before that the project's first prototype was developed around 19_. From that time onwards, your success with this technology likely depended, at least in part, on your control of resources which were not directly linked to the technology itself and on your ability to protect the innovation from imitation by others through intellectual property protection. Let's first consider how important your firm's control over resources has been in earning profits from this innovation. For each factor below, rate the importance over access and control of this resource on a scale from 1 to 5. A rating of " 5 " would mean that control over this resource was critical for earning profits from this innovation while a "1" would imply that control over this resource was not important at all.

The capability to manufacture the product

The principal distribution channels for the technology

The association of the technology with a well-known brand name or the development of a brand name for the product through marketing or advertising Control over the sales force and servicing resources for this product or technology

$\begin{array}{lllll}\text { LOW } & & & & \text { HIGH } \\ 1 & 2 & 3 & 4 & 5 \\ 1 & 2 & 3 & 4 & 5 \\ 1 & 2 & 3 & 4 & 5 \\ & & & & \\ 1 & 2 & 3 & 4 & 5\end{array}$

Now, let's turn to your ability to protect the innovation from imitation by others through intellectual property protection. For each factor below, rate the effectiveness of each factor in deterring imitation of the technology on a scale from 1 to 5 . A rating of " 5 " would mean that this factor was very effective in deterring imitation of the technology while a rating of "1" implies that this factor had no impact on your ability to deter imitation.

\begin{tabular}{llllll} 
& LOW & \multicolumn{3}{c}{ HIGH } \\
Trade secrecy & 1 & 2 & 3 & 4 & 5 \\
Patents \& copyright protection & 1 & 2 & 3 & 4 & 5 \\
Active patent or copyright litigation & 1 & 2 & 3 & 4 & 5
\end{tabular}

What activities were involved in the process of commercializing this technology and deciding how to earn returns from the innovation?

$\square$ Took an outside offer for purchasing the rights to the technology

$\square$ Shopped the technology around but was unable to sell a license to the technology

$\square$ Shopped the technology around and sold a license to the technology

$\square$ Did not shop the technology: Always had the intention of competing with the technology

$\square$ Other: 